\title{
One Health initiative in the Bolivian Altiplano human fascioliasis hyperendemic area: Lymnaeid biology, population dynamics, microecology and climatic factor influences
}

\author{
Aplicação do conceito One Health na área hiperendêmica de fasciolíase \\ humana do Altiplano Boliviano: biologia dos limneídeos, dinâmica \\ populacional, microecologia e influência de fatores climáticos
}

María Dolores Bargues* (D); René Angles²; José Coello3; Patricio Artigas; Ilra Renata Funatsu; Pablo Fernando Cuervo'; Paola Buchon ${ }^{4}$; Santiago Mas-Coma'

\author{
${ }^{1}$ Departamento de Parasitologia, Facultad de Farmacia, Universidad de Valencia, Valencia, Spain \\ ${ }^{2}$ Cátedra de Parasitología, Facultad de Medicina, Universidad Mayor de San Andrés - UMSA, La Paz, Bolivia \\ ${ }^{3}$ Laboratorio de Biología, Colegio "San Calixto", La Paz, Bolivia \\ ${ }^{4}$ Unidad de Limnología, Instituto de Ecología, Universidad Mayor de San Andrés - UMSA, Campus Universitario de Cota Cota, La Paz, \\ Bolivia
}

\begin{abstract}
How to cite: Bargues MD, Angles R, Coello J, Artigas P, Funatsu IR, Cuervo PF, et al. One Health initiative in the Bolivian Altiplano human fascioliasis hyperendemic area: Lymnaeid biology, population dynamics, microecology and climatic factor influences. Braz J Vet Parasitol 2021; 30(2): e025620. https://doi.org/10.1590/S1984-29612021014
\end{abstract}

\begin{abstract}
Fascioliasis is a freshwater snail-borne zoonotic disease. The Northern Bolivian Altiplano is a very high altitude endemic area where the highest human prevalences and intensities have been reported. Preventive chemotherapy by treatment campaigns is yearly applied. However, liver fluke infection of cattle, sheep, pigs and donkeys assures endemicity and consequent human infection and re-infection risks. A One Health action has therefore been implemented. Activity concerns lymnaeid vectors and environment diversity. Studies included growth, egg-laying and life span in laboratory-reared lymnaeids. Different habitat types and influencing factors were assessed. All populations proved to belong to Galba truncatula by rDNA sequencing. Analyses comprised physico-chemical characteristics and monthly follow-up of water temperature, $\mathrm{pH}$ and quantity, and lymnaeid abundance and density. Population dynamics in the transmission foci differed. Mean environmental temperature was lower than fluke development minimum temperature threshold, but water temperature was higher, except during winter. A two generations/year pattern appeared in permanent water habitats, and one generation/year pattern in habitats drying out for months. The multidisciplinary control measures can be extended from one part of the endemic area to another. These studies, made for the first time at very high altitude, constitute a baseline useful for fascioliasis control in other countries.
\end{abstract}

Keywords: Human and animal fascioliasis, lymnaeid vectors, experimental biology, population dynamics, climatic factors, Bolivian Altiplano.

\begin{abstract}
Resumo
A fasciolíase é uma doença zoonótica transmitida para os humanos por formas evolucionárias de Fasciola hepatica oriundas de limneídeos infectados. O Altiplano Boliviano Norte é uma área endêmica de altitude muito alta, onde foram relatadas as maiores prevalências e intensidades em infecções humanas. A quimioterapia preventiva por campanhas de tratamento é aplicada anualmente. No entanto, infecção por Fasciola hepatica em bovinos, ovelhas, suínos e asininos garante endemicidade e consequentes riscos de infecção e reinfecção humana. Portanto, ações norteadas no conceito "One Health" foram implementadas. As atividades envolveram os limneídeos e a avaliação da diversidade de ambientes. Os estudos incluíram o crescimento, postura de ovos e expectativa de
\end{abstract}


vida de limneídeos criados em laboratório, bem como a avaliação da influência dos diferentes hábitats. Todas as populações foram identificadas como Galba truncatula por meio do sequenciamento de rDNA. As análises incluíram características físico-químicas e acompanhamento mensal da temperatura, pH, quantidade da água, abundância e densidade de limneídeos. A dinâmica populacional nos focos de transmissão diferiu. A temperatura ambiente média foi mais baixa do que o limite mínimo de temperatura do desenvolvimento do helminto, mas a temperatura da água foi mais alta, exceto durante o inverno. Um padrão de duas gerações/ano apareceu em hábitats com água permanente, enquanto um padrão de uma geração/ano foi observado em hábitats que ficam secos durante meses. Os resultados permitem concluir que as medidas multidisciplinares de controle podem ser estendidas de uma parte da área endêmica para outra. Esses estudos, realizados pela primeira vez em altitudes muito elevadas, constituem uma base útil e extrapolável para o controle da fasciolíase.

Palavras-chave: Fasciolíase humana e animal, limneídeos vetores, biologia experimental, dinâmica populacional, fatores climáticos, Altiplano boliviano.

\section{Introduction}

Fascioliasis is a worldwide freshwater snail-borne zoonotic parasitic disease caused by $F$. hepatica, distributed in Europe, Asia, Africa, the Americas and Oceania, and F. gigantica restricted to Africa and Asia (Mas-Coma et al., 2009a). Its veterinary importance is due to the great losses it causes in livestock husbandry (Mehmood et al., 2017). The importance of human fascioliasis was recognized from the 1990 decade onwards (Chen \& Mott, 1990; MasComa et al., 2014a). Its high pathogenicity (Mas-Coma et al., 2014b; González-Miguel et al., 2019) in both the acute and chronic phases (Valero et al., 2006, 2008, 2016) led the World Health Organization (WHO) to include fascioliasis within the list of main neglected tropical diseases (WHO, 2013). The large diversity of human infection sources partly explain the large heterogeneity and complexity in transmission patterns and epidemiological situations of this disease (Mas-Coma et al., 2018).

The dependence of fascioliasis transmission on climatic factors (Ollerenshaw, 1959) underlie the marked influences of climate change on this disease. The impact of climate change has recently been demonstrated in human fascioliasis (Afshan et al., 2014), and also in animal fascioliasis (Mas-Coma et al., 2009b; Fox et al., 2011).

Latin America is the region in which more human fascioliasis endemic areas have been described. All these areas are at high altitude, as in Mexico (Zumaquero-Ríos et al., 2013), Peru (González et al., 2011; Valero et al., 2012a), Chile (Apt et al., 1993; Artigas et al., 2011), and Argentina (Malandrini et al., 2009; Mera y Sierra et al., 2011; Bargues et al., 2016). Many human cases have also been reported from altitude areas of Venezuela (Bargues et al., 2011a) and Colombia (Bargues et al., 2011b).

Bolivia stands out because of presenting the hyperendemic area where the highest prevalences (up to $72 \%$ by coprology) and intensities (up to more than 8,000 eggs of Fasciola per g of faeces) in humans have been reported (Hillyer et al., 1992; Bjorland et al., 1995; Esteban et al., 1997; Mas-Coma et al., 1999). The human fascioliasis endemic area is located in the Northern Bolivian Altiplano, between the Lake Titicaca, at 3,820 m altitude, and the city of El Alto, at around 4,100 m altitude, besides the valley of La Paz city, the capital of Bolivia. In 2007-2008, WHO decided to launch a preventive chemotherapy initiative by means of yearly triclabendazole monodose treatment campaigns focusing mainly on children (Villegas et al., 2012; Valero et al., 2012b).

Local efficacy monitorings performed in-between annual campaigns allowed for the detection of new infections and reinfections in children. Results proved a high infection risk, a great problem when considering the absence of premunition in Fasciola infection in humans and its immunological consequences (Gironés et al., 2007; Valero et al., 2017). In the Altiplano rural endemic area, livestock species, including cattle, sheep, pigs and donkeys, are crucial for community sustainability, because plant cultures are rarely practiced due to the extreme altitude conditions. Thus, liver fluke infection of these domestic animals assures fascioliasis endemicity and consequent human infection and re-infection risks.

The decision was taken to go for a One Health control action to decrease this infection risk. However, the very wide spread of the endemic area is not adequate for a One Health initiative, because of the impossibility to appropriately assess the so many multidisciplinary factors interacting in fascioliasis transmission. The One Health pilot initiative was therefore restricted to a small zone allowing for the correct monitoring of the different multidisciplinary interventions covering five main axes according to modern standards for such initiatives (Rinaldi et al., 2012; Webster et al., 2016): (i) lymnaeid snail vector populations; (ii) animal reservoirs; (iii) environment and its changing trends including climate change and anthropogenic modifications; (iv) human host; and (v) social, tradition and behavioural aspects.

Such a locally restricted One Health strategy is in need to verify that results obtained can be extended to the rest of the endemic area. The present work is part of these studies concerning the lymnaeid vectors, their environment 
diversity and changing trends. Therefore, after the necessary classification of the lymnaeid populations by DNA marker sequencing, combined experimental and field studies were performed. Laboratory studies included growth, egg-laying and life span in laboratory-reared snail cultures. Field studies focused on selected transmission foci, comprising physico-chemical characteristics of the freshwater collections, shell measurements in natural populations, and monthly follow-up of lymnaeid snail population abundance and density, and temperature, $\mathrm{pH}$ and quantity of the water collections. Air climatic variables were analyzed after their obtaining by interpolation from data from the closest meteorological stations.

This is the first time that such experimental and field studies are made with lymnaeid vectors from very high altitude. The importance of these studies should be highlighted because in Latin America most of the human fascioliasis endemic areas are located in high altitude zones. The selected objectives, the methodologies used and the way of presenting the results were designed considering their usefulness for health workers in charge for the implementation of control activities in the endemic area, a personnel usually lacking a background in this scientific field. The present work does therefore constitute a baseline useful for fascioliasis control in other countries.

\section{Materials and Methods}

\section{Snail habitat types studied}

The Northern Bolivian Altiplano human hyperendemic area includes three neighboring parallel, physiographically uniform, flatlands so-called "corridors" expanding between mountainous hill chains (Fuentes et al., 2001): (i) the most northern one extends from El Alto westward up to the Lake and including the villages of Pucarani and Batallas, and northward through Huarina up to Achacachi; (ii) the second "corridor" extends from the El Alto plain in the east up to the Lake Titicaca in the west and includes Tambillo and Huacullani; (iii) a southern "corridor" which extends east-west up to the Lake and including Tiwanaku and Guaqui (Figure 1).

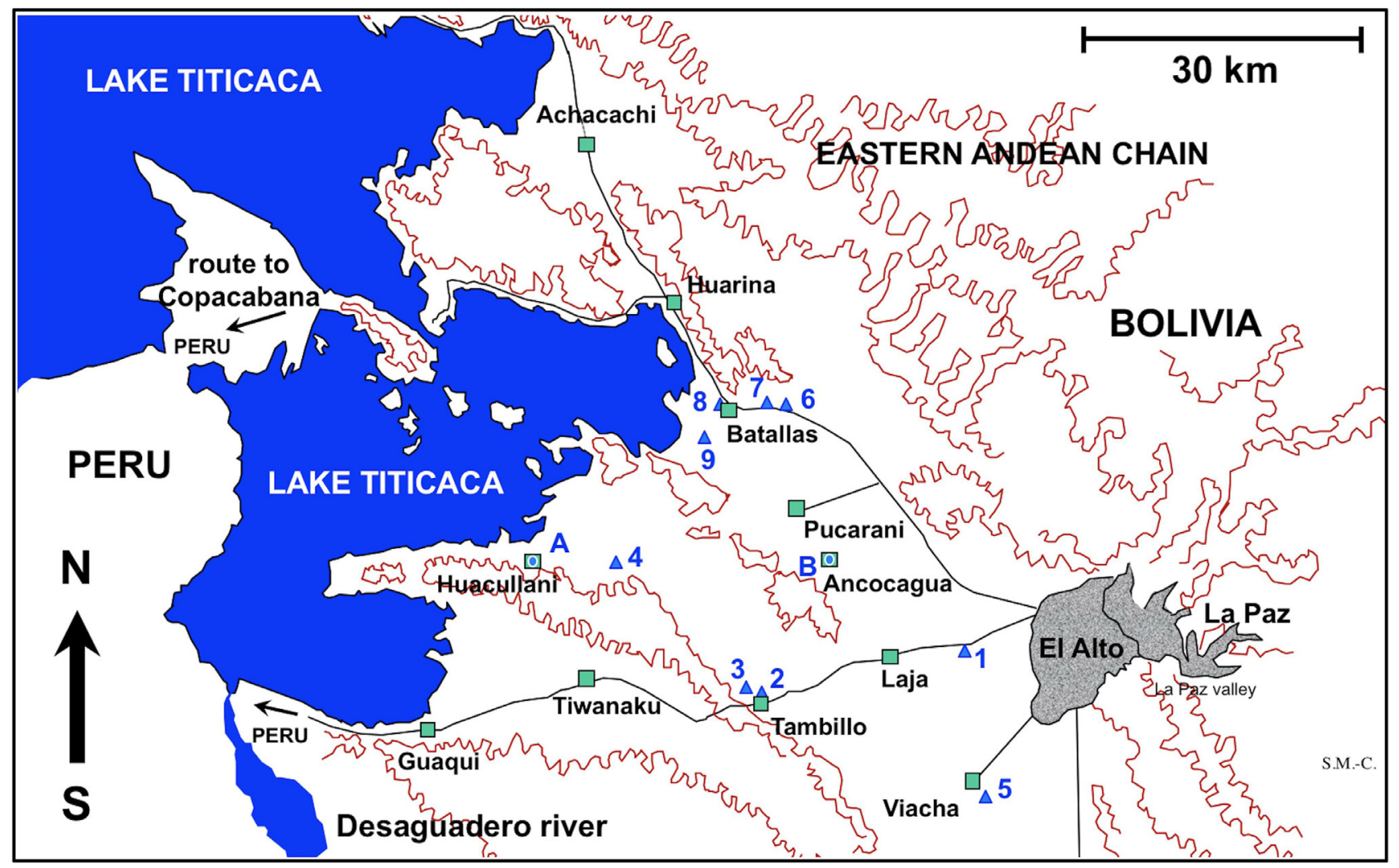

Figure 1. Northern Bolivian Altiplano human fascioliasis hyperendemic area: Map of altiplanic corridors between Lake Titicaca and the cities of El Alto and La Paz. Transmission foci monthly surveyed: 1) Kallutaca, 2) Tambillo 1, 3) Tambillo 2, 4) Quiripujo, 5) Rio Achicala, 6) Chirapaca 2, 7) Chirapaca 1, 8) Batallas, 9) Chijipata Alto. Other localities furnishing lymnaeids for additional experimental procedures: (A) Huacullani, (B) Ancocagua. 
The Lake Titicaca influences the climatic characteristics of its neighboring zones by moderating the extreme conditions of the very high altitude (Mas-Coma et al., 1999; Fuentes et al., 1999). Anthropogenic activities modifying the environmental characteristics are observed, usually close to small human communities or villages (Bargues et al., 2020).

The implementation of a One Health action to decrease the human risk of liver fluke infection was decided at a PAHO-WHO meeting in La Paz in 2014. Working axes of research and control, including experimental and field studies on the Altipanic lymnaeids, were designed in 2015 and implemented in the subsequent years 2016-2019 according to the availability of funds. A total of nine transmission foci were selected for a monthly follow-up of the lymnaeid snail vector population dynamics in different types of lymnaeid habitats and influencing factors, in all cases in localities where human and animal fascioliasis showed high prevalences and intensities. These foci were selected among the 57 lymnaeid-inhabited freshwater sites detected in past surveys, and in which around 14,000 specimens were collected and studied in different years and seasons (Bargues et al., 2020). The two very close Tambillo 1 and 2 habitats were prospected to assess the transmission characteristics in a human community. The two very close Chirapaca 1 and 2 foci were prospected to compare two neighboring habitats with temporary water collections. The geographical location and characteristics of each focus are detailed in Table 1 and in Figures 1 and 2.

Table 1. Characteristics of the nine fascioliasis transmission foci of the Northern Bolivian Altiplano human hyperendemic area in which the dynamics of the lymnaeid populations was followed by monthly standardized surveys.

\begin{tabular}{|c|c|c|c|c|c|}
\hline $\begin{array}{l}\text { Transmission } \\
\text { foci studied }\end{array}$ & $\begin{array}{c}\text { Habitat } \\
\text { characteristics }\end{array}$ & $\begin{array}{c}\text { Proximity to } \\
\text { livestock and/or } \\
\text { humans }\end{array}$ & $\begin{array}{l}\text { Distance from } \\
\text { Lake Titicaca }\end{array}$ & $\begin{array}{c}\text { Permanent/ } \\
\text { seasonal presence } \\
\text { of water }\end{array}$ & $\begin{array}{l}\text { Impact of human } \\
\text { activity }\end{array}$ \\
\hline Kallutaca & $\begin{array}{l}\text { canal with } \\
\text { neighboring } \\
\text { flooding } \\
\text { pastureland }\end{array}$ & besides cattle farm & far away & permanent & none \\
\hline Tambillo 1 & $\begin{array}{l}\text { small stream with } \\
\text { running polluted } \\
\text { water inside village }\end{array}$ & $\begin{array}{l}\text { inside small human } \\
\text { community }\end{array}$ & far away & permanent & $\begin{array}{l}\text { seasonal water } \\
\text { pollution due to } \\
\text { human waste }\end{array}$ \\
\hline Tambillo 2 & $\begin{array}{c}\text { same small stream } \\
\text { with cleaner running } \\
\text { water }\end{array}$ & $\begin{array}{l}\text { around } 30 \mathrm{~m} \\
\text { outside village }\end{array}$ & far away & permanent & $\begin{array}{l}\text { remaining pollution } \\
\text { from close village }\end{array}$ \\
\hline Quiripujo & $\begin{array}{l}\text { stagnant water in } \\
\text { lateral ditch besides } \\
\text { non-paved road } \\
\text { with water derived } \\
\text { from canal }\end{array}$ & $\begin{array}{l}\text { close to human } \\
\text { community }\end{array}$ & close & seasonal & none \\
\hline Rio Achicala & $\begin{array}{l}\text { river bankmarsh } \\
\text { with abundant } \\
\text { vegetation }\end{array}$ & $\begin{array}{c}\text { many livestock, } \\
\text { close to the large } \\
\text { human village of } \\
\text { Viacha }\end{array}$ & far away & permanent & none \\
\hline Chirapaca 2 & $\begin{array}{c}\text { canal besides paved } \\
\text { road }\end{array}$ & $\begin{array}{l}\text { close to human } \\
\text { community, isolated } \\
\text { ruminants }\end{array}$ & close & seasonal & none \\
\hline Chirapaca 1 & flooding grassland & $\begin{array}{l}\text { close to human } \\
\text { community, isolated } \\
\text { ruminants }\end{array}$ & close & seasonal & none \\
\hline Batallas & $\begin{array}{c}\text { man-controlled } \\
\text { small irrigation } \\
\text { canal }\end{array}$ & $\begin{array}{c}\text { in front of } \\
\text { slaughterhouse, } \\
\text { close to large } \\
\text { human community }\end{array}$ & close & permanent & $\begin{array}{l}\text { human } \\
\text { management of } \\
\text { canal irrigation }\end{array}$ \\
\hline Chijipata Alto & $\begin{array}{l}\text { small canal with } \\
\text { neighboring } \\
\text { flooding area }\end{array}$ & $\begin{array}{l}\text { in front of school } \\
\text { with very high } \\
\text { prevalence in } \\
\text { children }\end{array}$ & close & permanent & $\begin{array}{l}\text { flooding man-made } \\
\text { fountain }\end{array}$ \\
\hline
\end{tabular}



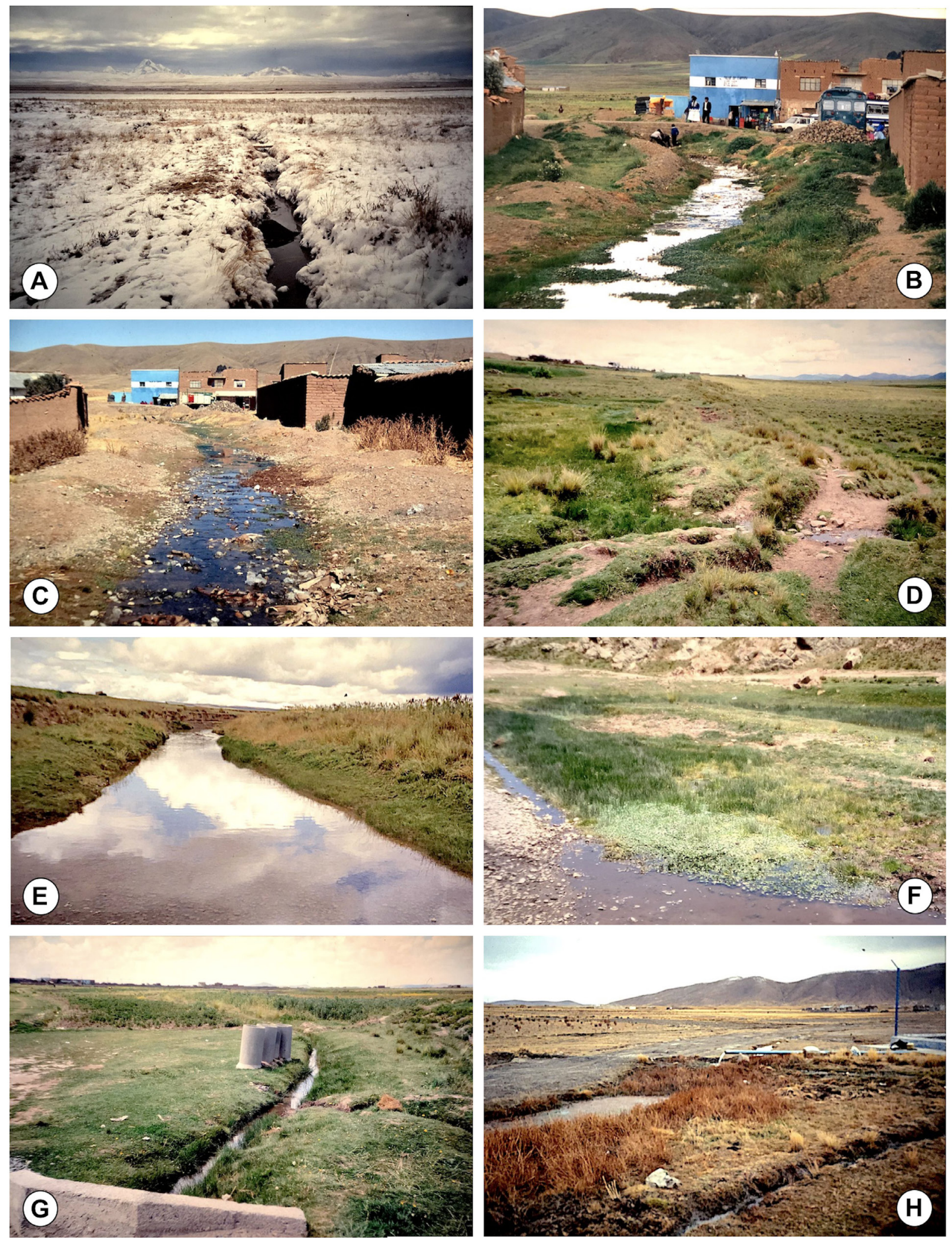

Figure 2. Monthly studied habitats inhabited by Galba truncatula in the Northern Bolivian Altiplano human fascioliasis hyperendemic area: (A) Kallutaca: canal with neighbouring flooding pastureland, besides cattle farm, covered by snow in July; (B) Tambillo 1: stream inside village (note aquatic vegetation) in March; (C) same stream (note absence of aquatic vegetation and abundant accumulated human waste) in June; (D) Quiripujo: stagnant water in lateral ditch with water derived from canal, in January; (E) Rio Achicala: river bankmarsh with abundant vegetation, in March; (F) Chirapaca 1: flooding zone, in March; (G) Batallas: man-controlled small irrigation canal in front of slaughterhouse, in February; (H) Chijipata Alto: small canal with neighbouring flooding area by artificial pipe, in June. 
Snail studies were conducted in freshwater sites between Lake Titicaca and the city of El Alto, because the water of Lake Titicaca is slightly saline (Boulangé \& Aquize Jaen, 1981; Dejoux \& Iltis, 1992) and lymnaeid vectors do not survive in a minimum presence of salts. All habitats surveyed were located on public land.

These field activities included monthly surveys which covered a complete twelve month period. They were designed to avoid cutting a climatic season, starting at the beginning of the dry season, i.e. in April, and finishing in March at the end of the rainy season.

\section{Molecular techniques}

Three lymnaeid specimens from each snail population studied were molecularly analyzed for species classification, including those followed up in field studies on the nine localities of Kallutaca, Tambillo 1, Tambillo 2, Quiripujo, Rio Achicala, Chirapaca 1, Chirapaca 2, Batallas, and Chijipata Alto, and additionally those used for experimental studies from Huacullani and Ancocagua (Figure 1). Two DNA markers useful for lymnaeid classification were sequenced: the complete nuclear ribosomal DNA (rDNA) spacers ITS-2 and ITS-1 (Bargues et al., 2007, 2011c).

Snail head-foot tissue fixed on ethanol $70 \%$ was used for DNA extraction, according to methods previously described (Bargues et al., 1997, 2017). The phenol-chloroform extraction and ethanol precipitation method was applied for total DNA isolation. This isolated DNA was later stored at $-20^{\circ} \mathrm{C}$ until use.

The ITS markers were PCR amplified independently for each specimen and each PCR product was sequenced for a bona-fide haplotype characterization. ITS-2 and ITS-1 were amplified using previously described primers (Bargues et al., 2003, 2007). Amplification procedures and thermal cycler conditions for each one of the DNA markers were carried out in a Mastercycle epgradient (Eppendorf, Hamburg, Germany) (Mas-Coma et al., 2009a; Bargues et al., 2011c).

The Ultra Clean ${ }^{\mathrm{TM}}$ PCR Clean-up DNA Purification System (MoBio, Solana Beach, CA, USA) was used for the purification of the PCR products, following the instructions of the manufacturer's protocol. They were subsequently resuspended in $50 \mu \mathrm{l}$ of $10 \mathrm{mM}$ TE buffer ( $\mathrm{pH} \mathrm{7.6).} \mathrm{The} \mathrm{absorbance} \mathrm{at} 260$ and $280 \mathrm{~nm}$ on a Eppendorf BioPhotometer (Hamburg, Germany) was measured to determine the final DNA concentration. The dideoxy chain-termination method was used for the sequencing on both strands with the Taq dye-terminator chemistry kit on an Applied Biosystems 3730 DNA Analyzer (Applied Biosystems, Foster City, CA, USA).

The complete sequences of ITS-2 and ITS-1 were edited and assembled by using Sequencher v5.4.6. (Gene Codes Co.). The alignments were made by using CLUSTALW2 (Larkin et al., 2007) in MEGA 6.0.6 (Tamura et al., 2013), applying default settings. Minor corrections for a better fit of nucleotide or indel correspondences were made. The BLASTN programme from the National Center for Biotechnology information website $(\mathrm{NBCl}, 2020)$ was used for the analysis of homologies. Analyses by sequence comparisons and haplotype identification of lymnaeids were made using data available in the GenBank.

The haplotype $(\mathrm{H})$ terminology used for the ITS-2 and ITS-1 sequences follows the standard nomenclature proposed for these snails (Mas-Coma et al., 2009a).

\section{Shell measurements}

A lymnaeid population from Batallas (Figure 1) was used to assess the shell morphometry variability in 60 specimens collected in the field. Another 60 specimens collected from Quiripujo (Figure 1) in the same day were used for comparison purposes (Samadi et al., 2000). These two localities are well known transmission foci and are representative of the two most important endemic corridors. Snails were assured to be free of infection by trematodes by verifying absence of cercarial shedding in Petri dishes containing natural water during $24 \mathrm{~h}$.

Altiplanic lymnaeid specimens studied have been deposited in the parasite/vector collection of the WHO Collaborating Centre on Fascioliasis and its snail Vectors at the Departamento de Parasitología, Facultad de Farmacia, Universidad de Valencia, Spain (WHO CC SPA-37 Collection voucher specimen references: G.tru/Bol/15.04.07.01-60 for material from Batallas; G.tru/Bol/15.04.07.61-120 for material from Quiripujo).

Shell measurements were made by means of a computer image analysis system (CIAS) (Valero et al., 2005). Measurements were taken using a stereo-microscope (Figure 3A). and images captured by a digital camera (Nikon Coolpix), and analyzed by image analysis software (ImagePro plus version 5.0 for Windows, Media Cybernetics, Silver Spring, Maryland, USA). Measurements were made according to a standardized proposal generally followed for lymnaeid snails (Hubendick, 1951). They included only the bare minimum useful for field work: shell length 


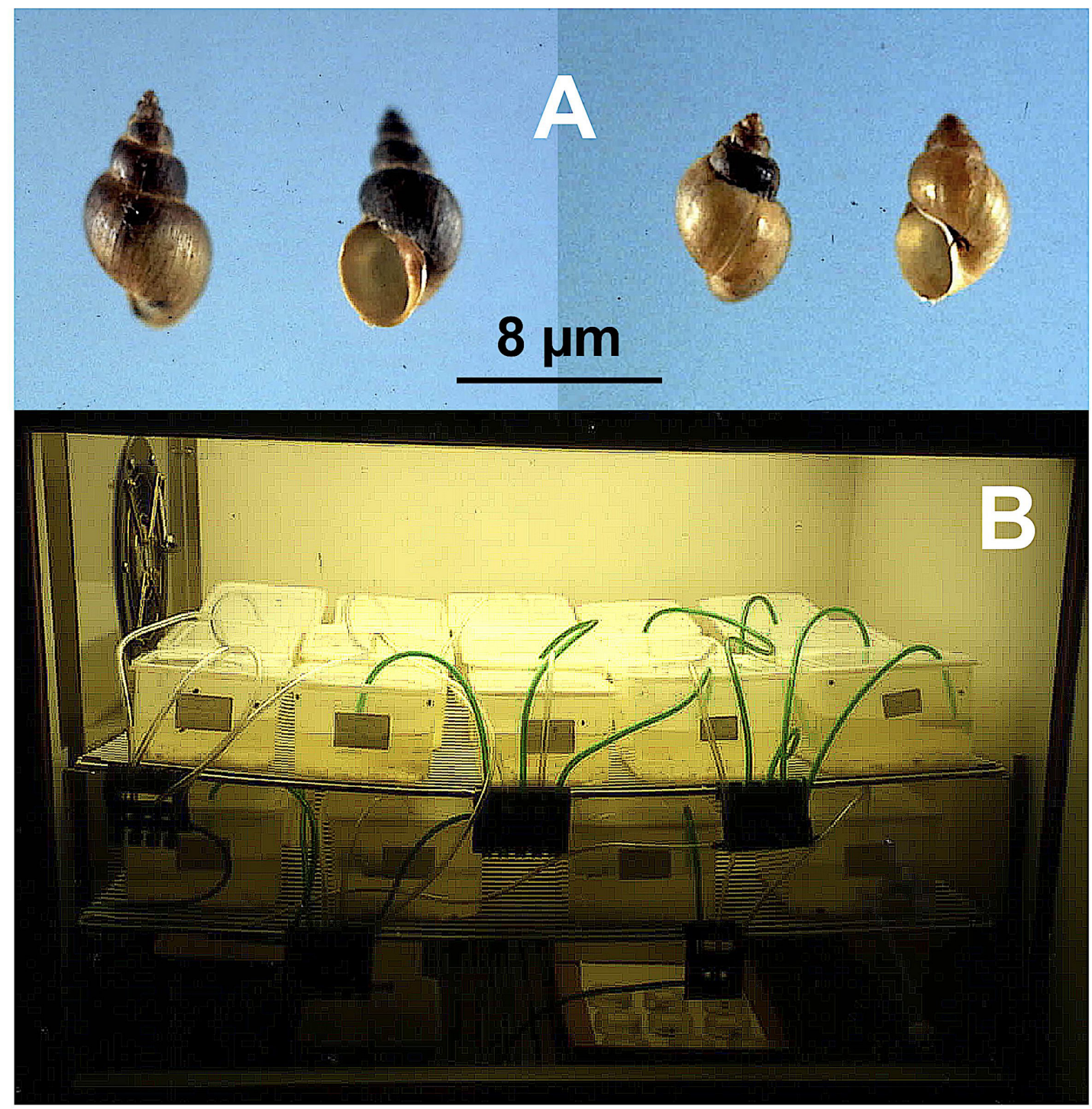

Figure 3. Morphology and culture methods of lymnaeid snails. (A) shells of Galba truncatula of the Northern Bolivian Altiplano showing intraspecific morphological variability of extreme morphs, in ventral and dorsal views; (B) breeding boxes containing $2000 \mathrm{ml}$ fresh water for the maintained of lymnaeids under experimentally controlled conditions of $20^{\circ} \mathrm{C}, 90 \%$ relative humidity and a $12 \mathrm{~h} / 12 \mathrm{~h}$ light/darkness photoperiod in precision climatic chambers in which day sunlight was of 3500 lux.

$(S L)$, shell width (SW), aperture length (AL), aperture width (AW), and body whorl length (BWL) (Table 2). All of the material used was measured by the same person. Absolute measurements are noted to illustrate the size of snail vectors to health workers in charge for field control activities.

\section{Snail laboratory cultures for the assessment of growth, egg-laying and life span}

Living lymnaeids collected in Batallas (Table 2) and other localities (Table 3) were used for experimental procedures, always after discarding a possible natural infection by fasciolids or other trematodes. Non-infected lymnaeids were arranged in breeding boxes containing $2000 \mathrm{ml}$ fresh water and maintained under controlled conditions of $20^{\circ} \mathrm{C}, 90 \%$ relative humidity and a $12 \mathrm{~h} / 12 \mathrm{~h}$ light/darkness photoperiod in precision climatic chambers in which day sunlight was of 3500 lux (Heraeus-Vötsch VB-0714 and HPS-500) (Figure 3B). The water was changed weekly and lettuce added ad libitum (Bargues et al., 2011c).

Follow up studies were made in the first laboratory-born generation to avoid potential ecological and behavioral modifications induced by laboratory adaptation (i.e., to keep origin environmental effects as much as possible). A total of 48 eggs laid on the same day, very early after initial laboratory adaptation of field-collected snails, and the 
Table 2. Shell morphometry of laboratory-reared and natural lymnaeid populations in two different localities of the Northern Bolivian Altiplano human fascioliasis hyperendemic area. Measurements in $\mathrm{mm}$ (mean values \pm standard deviation).

\begin{tabular}{|c|c|c|c|c|c|c|c|}
\hline \multirow{5}{*}{$\begin{array}{c}\text { Shell } \\
\text { characteristics }\end{array}$} & \multirow{5}{*}{ Abbreviations } & \multicolumn{4}{|c|}{ Laboratory-reared population } & \multicolumn{2}{|c|}{ Natural populations } \\
\hline & & \multicolumn{4}{|c|}{ Batallas } & \multirow{2}{*}{$\begin{array}{c}\text { Batallas } \\
n=60\end{array}$} & \multirow{2}{*}{$\begin{array}{c}\text { Quiripujo } \\
n=60\end{array}$} \\
\hline & & \multirow{2}{*}{\multicolumn{3}{|c|}{ Optimum period for miracidial infection }} & & & \\
\hline & & & & & \multirow{2}{*}{$\begin{array}{c}\begin{array}{c}\text { Maximum } \\
\text { size }\end{array} \\
\text { at week } 12\end{array}$} & \multirow{2}{*}{$\begin{array}{l}\text { different } \\
\text { ages }\end{array}$} & \multirow{2}{*}{$\begin{array}{l}\text { different } \\
\text { ages }\end{array}$} \\
\hline & & at week 4 & at week 5 & at week 6 & & & \\
\hline Shell length & SL & $4.39 \pm 0.34$ & $4.73 \pm 0.37$ & $4.98 \pm 0.41$ & $6.19 \pm 0.55$ & $4.78 \pm 1.81$ & $6.57 \pm 2.31$ \\
\hline Shell width & SW & $2.58 \pm 0.16$ & $2.75 \pm 0.18$ & $2.88 \pm 0.22$ & $3.58 \pm 0.28$ & $3.02 \pm 1.18$ & $3.65 \pm 1.28$ \\
\hline Aperture length & $A L$ & $2.27 \pm 0.14$ & $2.36 \pm 0.22$ & $2.47 \pm 0.25$ & $2.92 \pm 0.26$ & $2.62 \pm 1.13$ & $3.38 \pm 1.22$ \\
\hline Aperture width & AW & $1.47 \pm 0.15$ & $1.59 \pm 0.16$ & $1.64 \pm 0.17$ & $1.89 \pm 0.18$ & $1.90 \pm 0.77$ & $2.53 \pm 0.96$ \\
\hline Body whorl length & BWL & $3.45 \pm 0.21$ & $3.72 \pm 0.27$ & $3.90 \pm 0.33$ & $4.72 \pm 0.40$ & $3.78 \pm 1.20$ & $4.90 \pm 1.73$ \\
\hline
\end{tabular}

$\mathrm{n}=$ number of specimens.

Table 3. Total longevity (extreme and mean values) of lymnaeids from the Northern Bolivian Altiplano human fascioliasis hyperendemic area (days elapsed from birth) under experimental controlled conditions in the follow-up study in breeding boxes.

\begin{tabular}{|c|c|c|c|c|c|c|c|c|}
\hline \multirow[b]{2}{*}{$\begin{array}{l}\text { Expe- } \\
\text { riment No. }\end{array}$} & \multicolumn{3}{|c|}{ Experimental conditions in climate chamber } & \multirow[b]{2}{*}{$\begin{array}{l}\text { No. of } \\
\text { snails }\end{array}$} & \multirow[b]{2}{*}{$\begin{array}{l}\text { Locality origin } \\
\text { of snails }\end{array}$} & \multicolumn{3}{|c|}{ Total longevity } \\
\hline & $\begin{array}{l}\text { Temperature } \\
\left({ }^{\circ} \mathrm{C} \text { day } /{ }^{\circ} \mathrm{C} \text { night }\right)\end{array}$ & $\begin{array}{l}\text { Relative } \\
\text { humidity } \\
(\%+/-5 \%)\end{array}$ & $\begin{array}{l}\text { Photoperiod } \\
\text { (h day/h night) }\end{array}$ & & & $\begin{array}{l}\text { Extreme } \\
\text { values } \\
\text { (days) }\end{array}$ & $\begin{array}{l}\text { Mean } \\
\text { (days) }\end{array}$ & $\begin{array}{l}\text { Values } \\
\text { (months) }\end{array}$ \\
\hline 1 & $20 / 20$ & 90 & $12 / 12$ & 25 & Ancocagua & $79-226$ & $100.5(a)$ & $3-4$ \\
\hline 2 & " & " & !" & 30 & Ancocagua & $82-167$ & $115.8(a)$ & $3-4$ \\
\hline 3 & " & " & " & 12 & Huacullani & $128-274$ & $186.4(b)$ & $6-7$ \\
\hline 4 & " & " & " & 12 & Huacullani & $143-225$ & $185.3(b)$ & $6-7$ \\
\hline 5 & “" & " & " & 15 & Huacullani & $145-254$ & 190.0 (b) & $6-7$ \\
\hline 6 & " & " & " & 14 & Huacullani & $143-225$ & 185.3 (b) & $6-7$ \\
\hline 7 & $\stackrel{\prime}{\prime \prime}$ & " & " & 9 & Huacullani & $121-274$ & 194.5 (b) & $6-7$ \\
\hline 8 & $25 / 10$ & 90 & $12 / 12$ & 22 & Huacullani & $41-69$ & $52.8 \subset$ & $1-2$ \\
\hline 9 & $16 / 9$ & 65 & $12 / 12$ & 14 & Huacullani & $161-285$ & $242.5(d)$ & 8 \\
\hline 10 & ". & " & $\therefore$ & 21 & Huacullani & $171-275$ & $242.1(\mathrm{~d})$ & 8 \\
\hline 11 & $22 / 5$ & 65 & $12 / 12$ & 18 & Huacullani & $146-211$ & 182.9 (b) & $6-7$ \\
\hline 12 & " & " & " & 21 & Kallutaca & $223-368$ & $310.4(\mathrm{e})$ & $10-12$ \\
\hline 13 & " & " & ." & 38 & Batallas & $71-203$ & $150.8(f)$ & $5-6.5$ \\
\hline 14 & " & . & “" & 35 & Chijipata Alto & $98-203$ & $147.3(f)$ & $5-6.5$ \\
\hline
\end{tabular}

$(\mathrm{a})=$ experiments with significant similar results $(P<0.05)$; $(b)=$ experiments with significant similar results $(P<0.05)$; $(c)=$ experiment with a result significantly different from (b) $(P>0.05)$; $(d)=$ experiments with significant similar results $(P<0.05)$; $(e)=$ experiment with a result significantly different from those of all other $(P>0.05) ;(f)=$ experiments with significant similar results $(P<0.05)$. 
subsequent 48 living specimens born from these eggs, could be used for a follow-up period appropriately long as to assess the main epidemiological characteristics, including (i) time needed to reach the appropriate size for potential infection by $F$. hepatica, (ii) size ranges to enable the assessment of approximate snail age in field specimens, and (iii) size/age when egg laying starts. This number of 48 specimens was considered sufficient because of their successful complete follow-up (none died) and considering that this number fits the specimen quantity ranges traditionally used in experimental studies with this kind on snails. Well known problems posed by the laboratory keeping of living lymnaeids, to which the large problematics posed by their very high altitude strains should be added, underlie difficulties leading to experimental studies with low number of specimens (Rondelaud et al., 2009; Mas-Coma et al., 2020). Studies were as follows:

- Egg development: Egg clusters laid by lymnaeids from Batallas inside the breeding containers were isolated in Petri dishes, i.e. one cluster per Petri dish, and kept inside the climatic chambers under the same environmental conditions. Development of 48 eggs was daily followed-up to assess the embryonic period (from day of egg cluster laying to day of egg hatching);

- Shell growth: It was assessed in 48 specimens from Batallas. Immediately after egg hatching, each newborn snail specimen was isolated in another small Petri dish provided with a thin freshwater layer and microalgae (Oscilatoria formosa) as food. Growth and egg cluster laying produced by selfing were thereafter followed on a daily basis. Small portions of fresh and boiled lettuce were added to complement the food diet when lymnaeid size was sufficient. This follow-up was up to 12 weeks. Shell measurements were as noted above for field collected snails;

- Life span: To assess the total longevity until snail death and life-long egg cluster laying capacity beyond the first 12 weeks, the daily follow up was made with other snail specimens isolated in breeding boxes. The size of the breeding boxes allowed the snails to come out from and re-enter into water, an important option for amphibious lymnaeids not available inside the Petri dishes due to the short height of their lateral walls. Snail number, their localities of origin and varying experimental conditions of temperature and relative humidity in each experimental follow-up are noted in Table 3. This follow-up in the breeding boxes was continued until snail death.

The following characteristics were assessed (Bargues et al., 2011c): (i) life span (= from day of hatching to day of death); (ii) pre-laying period (=from day of hatching to day when first cluster was laid); (iii) laying period (= from first to last day when clusters were laid by a snail specimen); (iv) number of eggs per cluster; and (v) egg laying capacity rate given as mean egg/lymnaeid specimen/month throughout its laying period.

\section{Environmental factors}

Freshwater and air were characterized for each transmission focus, including abiotic factors influencing liver fluke transmission (Mas-Coma et al., 1999; Fuentes et al., 1999):

- Physico-chemical characteristics of the freshwater collections were studied to assess potential relationships with lymnaeid population dynamics. Water samples were collected during the day in the February-March period. Analytical methods used were: American Public Health Association (APHA) methods for $\mathrm{pH}$ and electric conductivity (Baird et al., 2017); Hach methods for colour, FTU (Formacine-Nephelometric Units) turbidity, solids in suspension, phosphates, sulphates, nitrites, nitrates, and ammoniacal nitrogen; flame emission for sodium and potassium; and atomic absorption for calcium and magnesium (Hach Company, 2012);

- Special focus was given to water temperature and $\mathrm{pH}$. A field thermometer and $\mathrm{pH}$-meter were therefore used in each monthly survey. Water presence/absence and its level fluctuations (= depth) were noted;

- Monthly air climatic variables were obtained by interpolation based on data furnished by the closest surrounding meteorological stations. The interpolation method was by nearest neighbour by using the New LocClim 1.10 software from FAO with a temporal resolution of days (Bargues et al., 2016). Climatic data registered in the meteorological stations were provided by the Servicio Nacional de Meteorologia e Hidrologia del Ministerio de Transportes, Comunicaciones y Aeronautica Civil (La Paz, Bolivia): Ayo Ayo

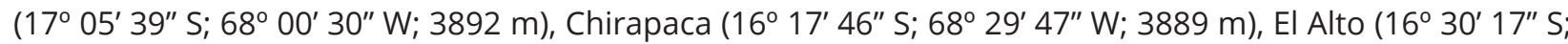

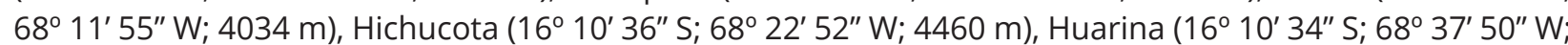

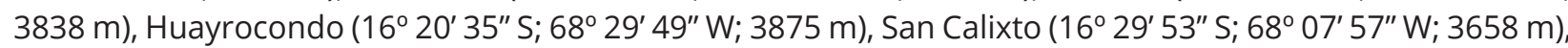

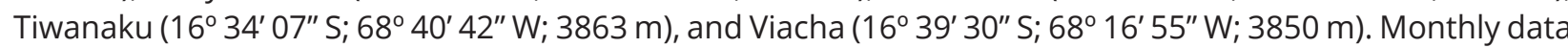
analyzed included mean environmental temperature (MET), mean maximum temperature (MMT), and mean minimum temperature $(\mathrm{MmT})$ in ${ }^{\circ} \mathrm{C}$, precipitation $(\mathrm{Pt})$ in $\mathrm{mm}$, number of days with precipitation $(\mathrm{rD})$, relative 
humidity (RH) in \%, total evaporation (TEv) and potential evapotranspiration (PET) in mm (Fuentes et al., 1999).

Field studies on lymnaeid snail population abundance and density

A standard method of collection was used to allow for meaningful comparisons between and inside the nine transmission foci. Freshwater snails were collected using the man-time collection method (Relf et al., 2011; Charlier et al., 2014). Abundance was estimated by the total number of lymnaeids collected in a given site during a 30-minute time. To reflect aggregation/dispersion, density was established as the mean number of lymnaeid specimens collected during 1 minute, calculated from an uninterrupted 15-minute period (within the aforementioned 30-minute period to establish the abundance) on a searching circle of a radius of a maximum of $5 \mathrm{~m}$ (Figure 4). Such a circle allowed to follow population movements within the same focus (Figure 4). Surveys were always made by the same person. Snail collection was made between 10.00 h a.m. and 01.00 h p.m. of sunny days, in each collection site, using appropriate forceps with flat clamps.
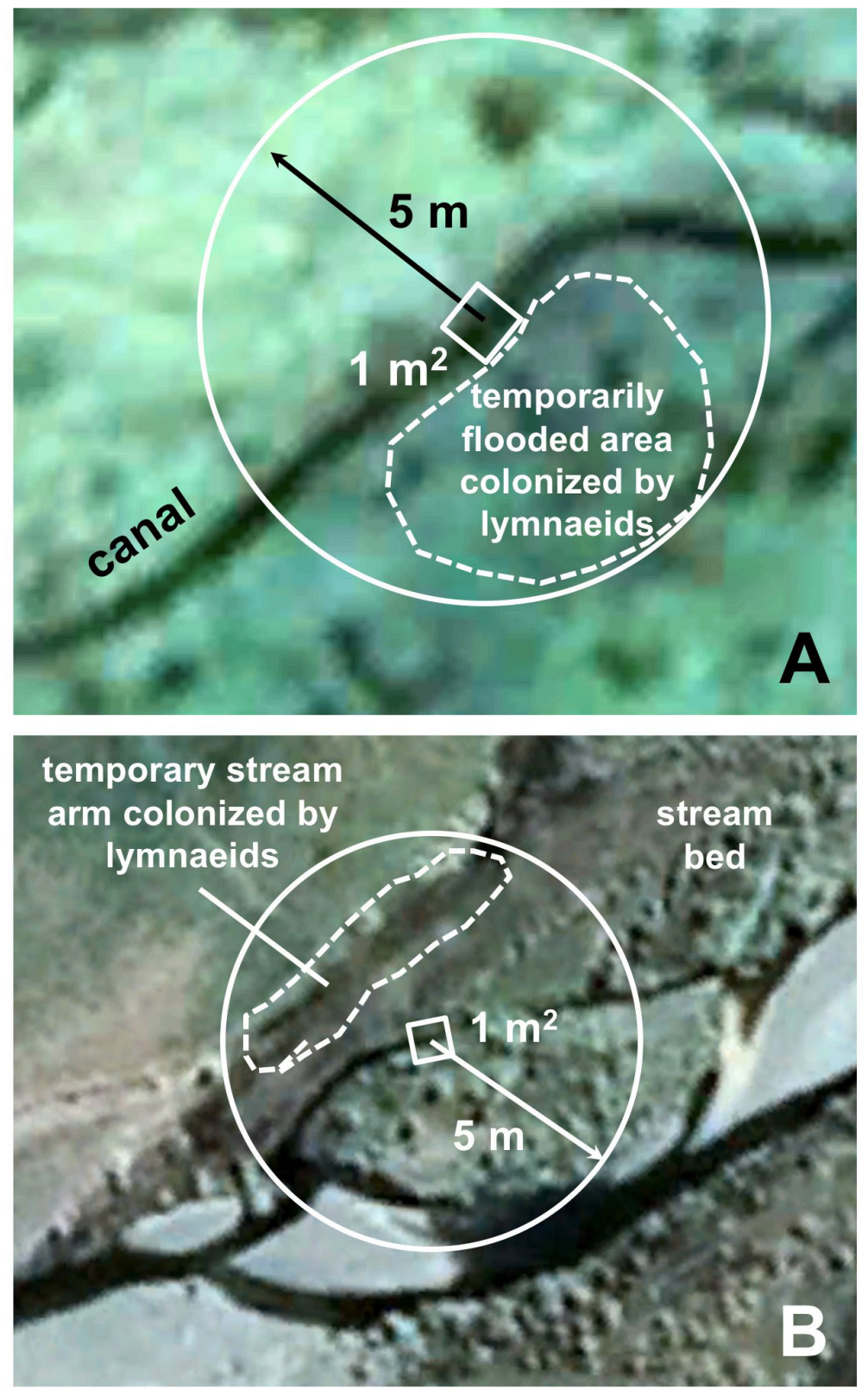

Figure 4. Standardized methodology for lymnaeid snail collection and population abundance and density estimates by monthly surveys, allowing for the follow up of population movements within the same fascioliasis transmission focus. Examples of (A) temporarily flooded area colonized by lymnaeids from neighboring water canal, and (B) temporary stream arm colonized by lymnaeids from another close water arm in wide flat stream bed. See text for further details. 
Collected snails were put in a clean plastic container to differentiate lymnaeids from other snails by their typical small, smooth and dextral conical shell, and their pair of triangular tentacles with darkly pigmented eyes at their bases. There are no other freshwater snails in the Northern Altiplano which may be confused with lymnaeids. After lymnaeid counting, they were released in the same place to avoid disturbing their population dynamics.

Pronounced changes of water quantity and of the extent and density of the vegetation coverage, mainly by Ranunculaceae, Juncaceae and many other freshwater plants (Mas-Coma et al., 1999), did not allow for accurate abundance and density studies of small specimens, because many of which remain undetected under dense vegetation. Therefore, a distinction of age groups according to size, as made in other similar lymnaeid population studies in farms, flat grasslands, rice cultures or controlled pasturelands (Relf et al., 2011; Charlier et al., 2014), could not be performed. The same problem was already highlighted in field surveys on Galba/Fossaria species in Europe (Simon Vicente, 1968).

In the last $12^{\text {th }}$ monthly survey, ten lymnaeid specimens from each followed-up population were fixed in $96 \%$ ethanol, of which three were used for DNA sequencing.

\section{Statistical analyses}

The Student's t-test and non-parametric Mann-Whitney test were used to compare the experimental life spans of lymnaeids between different localities and between different experimental conditions. Bivariant correlations (Pearson's correlation) were calculated for lymnaeid population dynamics (monthly values of abundance and density) versus mean monthly climatic variables of the transmission foci, also versus the values of the physicochemical characteristics of the freshwater collections, and finally also versus the monthly values of freshwater characteristics (presence/absence, temperature and $\mathrm{pH}$ ). Data processing was carried out with SPSS version 6.1 for Macintosh (SPSS Inc., Chicago, IL).

\section{Results}

\section{DNA characterization of lymnaeid specimens}

Ribosomal DNA ITS-2 and ITS-1 markers allowed for the verification of the systematic classification of the populations studied.

All 33 specimens from the eleven lymnaeid populations showed an identical ITS-2 sequence of a length of 401 bp and a 58.60\% GC content. This sequence shows no nucleotide difference with the haplotype G.tru-H3 (GenBank AJ272051) of G. truncatula. This haplotype has already been reported from Bolivia, Chile and Argentina.

Moreover, all specimens presented the same 504-bp-long ITS-1 sequence, with a 57.53\% GC content. This ITS-1 shows no nucleotide difference with the haplotype G.tru-HC (GenBank AJ272052) of the same species. Similarly, this ITS-1 haplotype has been previously reported in Bolivia, Chile and Argentina.

\section{Experimental results}

The growth curve obtained by following 48 specimens from Batallas agrees with the shell size ranges of lymnaeids in the field (Table 2, Figure 5A, B). After an embryonic period of 11-14 days (mean 12.1 days), lymnaeid growth shows a very fast development of around $1 \mathrm{~mm}$ increase in length per week. This leads the lymnaeids to reach the optimum size ( $4 \mathrm{~mm}$ length) for liver fluke miracidial infection 3 days before week 4 (Table 2, Figure 5A, B).

As a consequence of self-fertilization, lymnaeids individually isolated in Petri dishes began to lay the first egg clusters during week 4, in several specimens even 1-2 days before (pre-laying period). The total laying period, followed up in breeding boxes, proved to be very long and continuous until almost the death. At the beginning of the egg laying period the rounded-oval small clusters included a reduced number of eggs (2-4) measuring around $700 \times 600$ $\mu \mathrm{m}$. However, with time these clusters increased in size, became more oval and slightly elongate, and the number of eggs per cluster increased considerably. So, a high egg laying capacity of 9-33 eggs per cluster (mean 17.5 eggs/ cluster) appeared and a mean of 87.1 eggs/snail/month was reached and maintained throughout a whole year.

Regarding experiments for lymnaeid longevity assessment, similar results were obtained when using lymnaeids from the same locality, e.g. Huacullani, under the same environmental conditions (assays Nos. 3-7 in Table 3), sometimes even when under day-night changing conditions (assay No. 11 in Table 3), although this was not always 

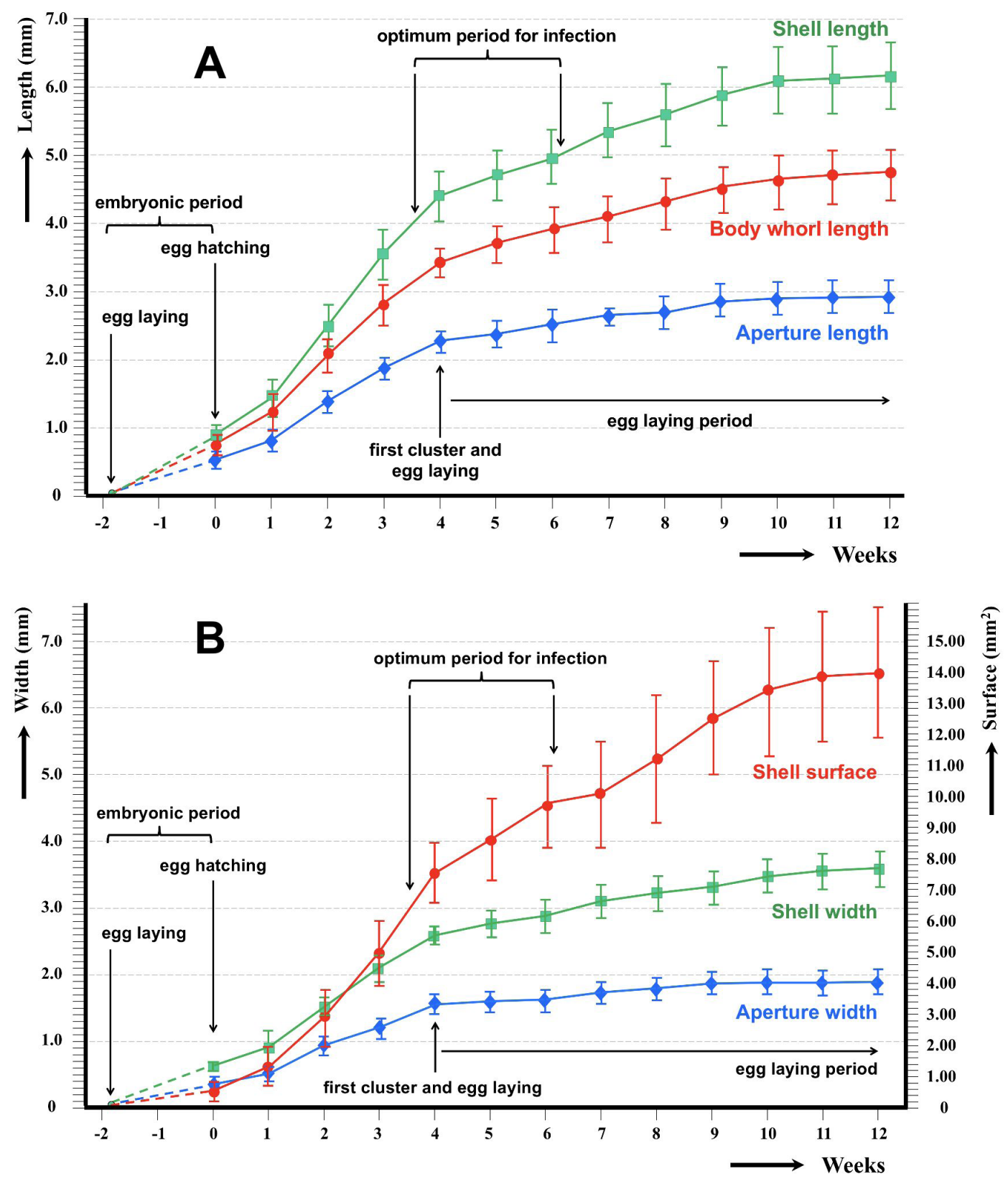

Figure 5. Experimentally followed shell growth (mean values \pm standard deviation SD) of Galba truncatula from the Northern Bolivian Altiplano human fascioliasis hyperendemic area: (A) lengths of shell, body whorl and aperture; (B) widths of shell and aperture and shell surface. Note embryonic period, optimum period for infection by Fasciola hepatica, and egg laying period.

the case (assay No. 8 in Table 3). A similar life span was observed in the two experiments with lymnaeids from Ancocagua (assays Nos. 1 and 2 in Table 3), and also in lymnaeids from Batallas and Chijipata Alto (assays Nos. 13 and 14 in Table 3), the latter two localities geographically very close one another (see Figure 1). Life spans of lymnaeids from different localities differed significantly $(P<0.05)$.

Worth mentioning are assays carried out under temperatures differing during day and night hours. In lymnaeids from Huacullani under $22^{\circ} \mathrm{C} / 5^{\circ} \mathrm{C}$ day/night temperatures (assay No. 11 in Table 3), the life span was similar to that obtained under a $24 \mathrm{~h}$-constant temperature of $20^{\circ} \mathrm{C}$ (assays Nos. 3-7 in Table 3). Huacullani lymnaeids analyzed under $16^{\circ} \mathrm{C} / 9^{\circ} \mathrm{C}$ day/night (assays Nos. 9 and 10 in Table 3) showed an unexpected high longevity, whereas when under $25^{\circ} \mathrm{C} / 10^{\circ} \mathrm{C}$ day/night (assay No. 8 in Table 3) lymnaeids from this locality provided a markedly shorter longevity which proved to be statistically significant $(P<0.05)$. According to what happens in the Bolivian Altiplano in winter, the experimental relative humidity was decreased from $90 \%$ to $65 \%$ when applying colder temperatures of $16^{\circ} \mathrm{C} / 9$ 
${ }^{\circ} \mathrm{C}$ and $22^{\circ} \mathrm{C} / 5^{\circ} \mathrm{C}$ day/night (assays 9-14 in Table 3), and the lymnaeid life spans obtained were pronouncedly longer than that obtained at $90 \%$ relative humidity but under $25^{\circ} \mathrm{C} / 10^{\circ} \mathrm{C}$ day/night (assay No. 8 in Table 3).

The life span was of 10-12 months depending on locality origins and experimental conditions (Table 3). The longest was observed in lymnaeids from Kallutaca under temperatures of $22^{\circ} \mathrm{C} / 5^{\circ} \mathrm{C}$ day/night (assay No. 12 in Table 3). It should be remembered here that all these results concern lymnaeids of the first laboratory-reared generation. After years of adaptation to standard laboratory conditions in breeding boxes at $20^{\circ} \mathrm{C} / 20^{\circ} \mathrm{C}$ day/night and $90 \%+5 \%$ relative humidity, lymnaeids descending from field collected specimens from the Altiplano were sometimes observed to survive up to 13-14 months.

\section{Climatic characteristics of the transmission foci surveyed}

Local climatic factor curves slightly differed from one transmission focus to another (Figures 6 and 7). However, due to geographic closeness, no differences were observed between Tambillo 1 and Tambillo 2 (Figure 6), between Chirapaca 1 and Chirapaca 2 (Figure 7), and between Batallas and Chijipata Alto (Figure 7).

No marked seasonality appears according to the temperatures, monthly fluctuations being relatively scarce except in the mean minimum temperature during winter. The mean environmental temperature is kept below $10^{\circ} \mathrm{C}$ throughout the whole 12 month period and the mean maximum temperature does not reach the level of $20^{\circ} \mathrm{C}$ in any of the transmission foci studied. The mean minimum temperature reaches its lowest level, below $0{ }^{\circ} \mathrm{C}$
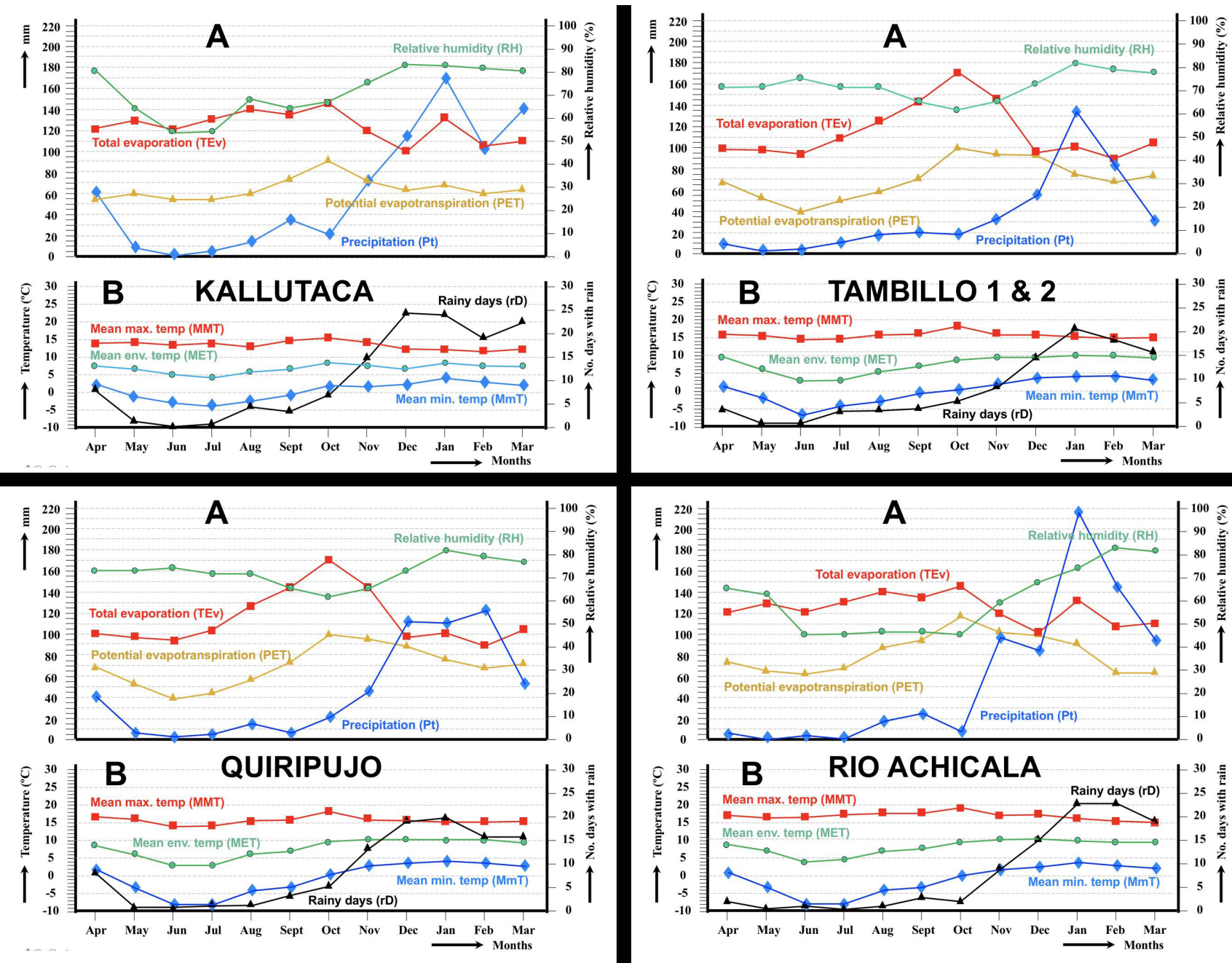

Figure 6. Mean monthly data of climatic factors in the transmission foci of Kallutaca, Tambillo 1, Tambillo 2, Quiripujo and Rio Achicala: $(\mathrm{A})$ precipitation $(\mathrm{Pt})$, relative humidity $(\mathrm{RH})$, total evaporation $(\mathrm{TEv})$ and potential evapotranspiration $\mathrm{PET})$; (B) mean environmental temperature (MET), mean maximum temperature (MMT), mean minimum temperature (MmT), and number of days with precipitation (rD). 

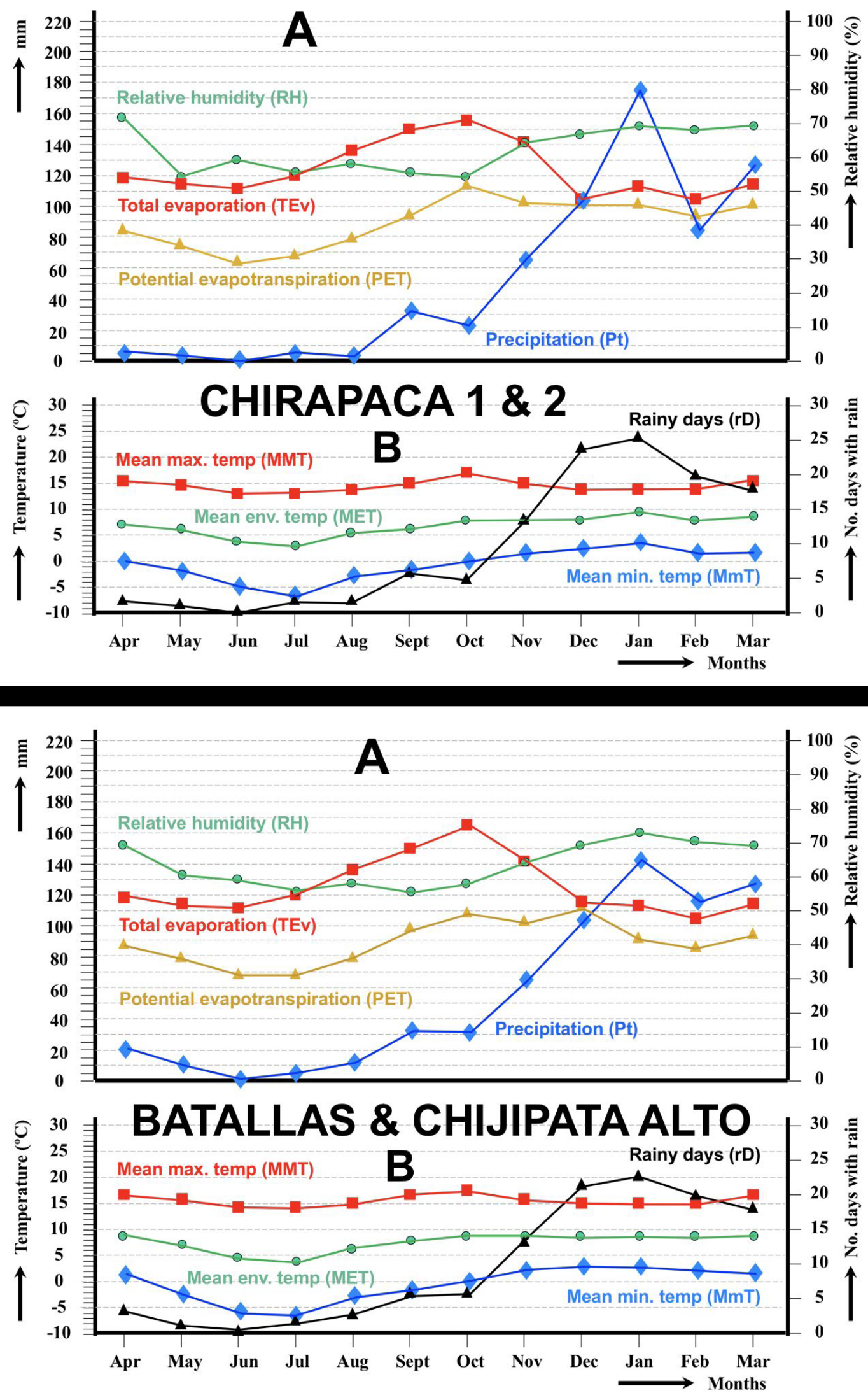

Figure 7. Mean monthly data of climatic factors in the transmission foci of Chirapaca 1 and 2, Batallas and Chijipata Alto: (A) precipitation $(\mathrm{Pt})$, relative humidity $(\mathrm{RH})$, total evaporation (TEv) and potential evapotranspiration PET); (B) mean environmental temperature (MET), mean maximum temperature (MMT), mean minimum temperature (MmT), and number of days with precipitation ( $\mathrm{rD})$. 
and in given foci even lower than $-5^{\circ} \mathrm{C}$ and close to $-10{ }^{\circ} \mathrm{C}$ as in Quiripujo and Rio Achicala (Figure 6), in the winter months of June and July, that is in the peak of the dry season.

Precipitation and number of days with precipitation allow to distinguish between a dry season from May to September and a rainy season from October to April, with a precipitation peak in January. Total evaporation and potential evapotranspiration are very high and show a peak in October in all transmission foci studied (Figures 6 and 7).

\section{Characteristics of the water collections surveyed}

No significant relationship appeared between each one of the physico-chemical characteristics of water (Table 4) and the lymnaeid population dynamics in each focus, not even when separately grouping foci with permanent water presence and foci with temporary absence of water (Figures $8 \mathrm{~A}$ and $9 \mathrm{~A}$ ).

The monthly values of water $\mathrm{pH}$ throughout the twelve month period varied between 5.5 and 8.5 , although extreme values were only sporadically obtained, and an acid trend was found in most of the habitats (Figures 8B and 9B). Water temperature showed evident fluctuations in given foci (Kallutaca, Tambillo and Batallas), whereas fluctuations appeared to be minor in others (Quiripujo, Chirapaca 1, Chirapaca 2 and Chijipata Alto). Monthly values of water temperature reached the minimum of $0^{\circ} \mathrm{C}$ only in July in Kallutaca, whereas a maximum of $25^{\circ} \mathrm{C}$ was only reached in September in Tambillo (Figure 8B and 9B).

\section{Abundance and density of the lymnaeid populations}

There were habitats in which lymnaeid snails were found in each monthly survey, such as Kallutaca, Rio Achicala (Figure 8C), Batallas and Chijipata Alto (Figure 9C). In other foci, no lymnaeids were found during several months,

Table 4. Physico-chemical characteristics of water samples obtained in the selected transmission foci of the Northern Bolivian Altiplano human fascioliasis hyperendemic area in which the lymnaeid population dynamics were followed up. Measurements performed during the day in the February-March period. Tambillo 1 and Tambillo 2 concerned two collecting sites in the same stream only separated $30 \mathrm{~m}$ one another and differing only by their distance from human dwellings.

\begin{tabular}{|c|c|c|c|c|c|c|c|c|c|}
\hline Characteristics & Units & Kallutaca & $\begin{array}{c}\text { Tambillo } \\
1 \& 2\end{array}$ & Quiripujo & $\begin{array}{c}\text { Rio } \\
\text { Achicala }\end{array}$ & $\begin{array}{c}\text { Chirapaca } \\
2\end{array}$ & $\begin{array}{c}\text { Chirapaca } \\
1\end{array}$ & Batallas & $\begin{array}{c}\text { Chijipata } \\
\text { Alto }\end{array}$ \\
\hline Conductivity & $\mu \mathrm{S} / \mathrm{cm}$ & 199 & 332 & 600 & 244.00 & 78.00 & 363.00 & 102.00 & 57.00 \\
\hline Apparent color & $\mathrm{Pt} / \mathrm{Co}^{*}$ & 300.00 & 58.00 & $>500$ & 70.00 & 27.00 & 470.00 & 18.00 & 17.00 \\
\hline True color & $\mathrm{Pt} / \mathrm{Co}^{*}$ & 140.00 & 4.00 & 58.00 & 9.00 & 17.00 & 63.00 & 0.00 & 6.00 \\
\hline Turbidity & $\mathrm{FTU}^{+}$ & 50.00 & 0.00 & 240.00 & 15.00 & 7.00 & 80.00 & 0.00 & 0.00 \\
\hline $\begin{array}{l}\text { Solids in } \\
\text { suspension }\end{array}$ & $\mathrm{mg} / \mathrm{l}$ & 20.00 & 0.00 & 360.00 & 10.00 & 0.00 & 160.00 & 0.00 & 0.00 \\
\hline Total hardness & ${ }^{\circ} \mathrm{dH}^{\S}$ & 3.30 & 6.80 & indet. & 5.50 & 1.70 & 6.50 & 1.90 & 1.20 \\
\hline Alkalinity & meq/l & $<<20$ & indet. & indet. & $<<20$ & indet. & indet. & $<<20$ & $<<20$ \\
\hline Phosphates & $\mathrm{mg} \mathrm{PO}_{4} / \mathrm{I}$ & 0.79 & 0.06 & 1.23 & 0.00 & 0.02 & 0.47 & 0.05 & 0.00 \\
\hline Sulphates & $\mathrm{mg} \mathrm{SO}_{4} / \mathrm{I}$ & 15.00 & 57.0 & 28.00 & 0.00 & 14.00 & 45.00 & 13.00 & 18.00 \\
\hline Nitrites & $\mathrm{mg} \mathrm{NO}_{2} / \mathrm{l}$ & --- & --- & -- & 0.000 & --- & 0.000 & --- & --- \\
\hline Nitrates & $\mathrm{mg} \mathrm{NO}_{3} / \mathrm{l}$ & 0.00 & 0.04 & 0.08 & 0.03 & 0.00 & 0.03 & 0.02 & 0.01 \\
\hline $\begin{array}{c}\text { Ammoniacal } \\
\text { nitrogen }\end{array}$ & $\mathrm{mg} \mathrm{NH}_{4} / \mathrm{I}$ & 0.43 & 0.03 & 0.30 & 0.10 & 0.08 & 0.29 & 0.03 & 0.02 \\
\hline Sodium & $\mathrm{mg} \mathrm{Na/l}$ & 30.10 & 20.70 & 36.40 & 36.40 & 4.70 & 33.80. & 6.30 & 2.90 \\
\hline Potassium & $\mathrm{mg} \mathrm{K} / \mathrm{l}$ & 20.10 & 10.40 & 27.80 & 41.00 & 1.90 & 27.80 & 3.70 & 2.80 \\
\hline Calcium & mg Ca/l & 10.80 & 49.10 & 94.60 & 24.10 & 7.10 & 29.60 & 8.50 & 5.70 \\
\hline Magnesium & mg Mg/l & 8.10 & 6.30 & 16.90 & 8.30 & 2.40 & 11.10 & 3.30 & 1.30 \\
\hline
\end{tabular}

*Pt/Co = units of Chloroplatinate; † FTU = Formacine-Turbidity Units; $\S^{\circ} \mathrm{dH}=$ German hardness degrees; indet. = could not be determined. 


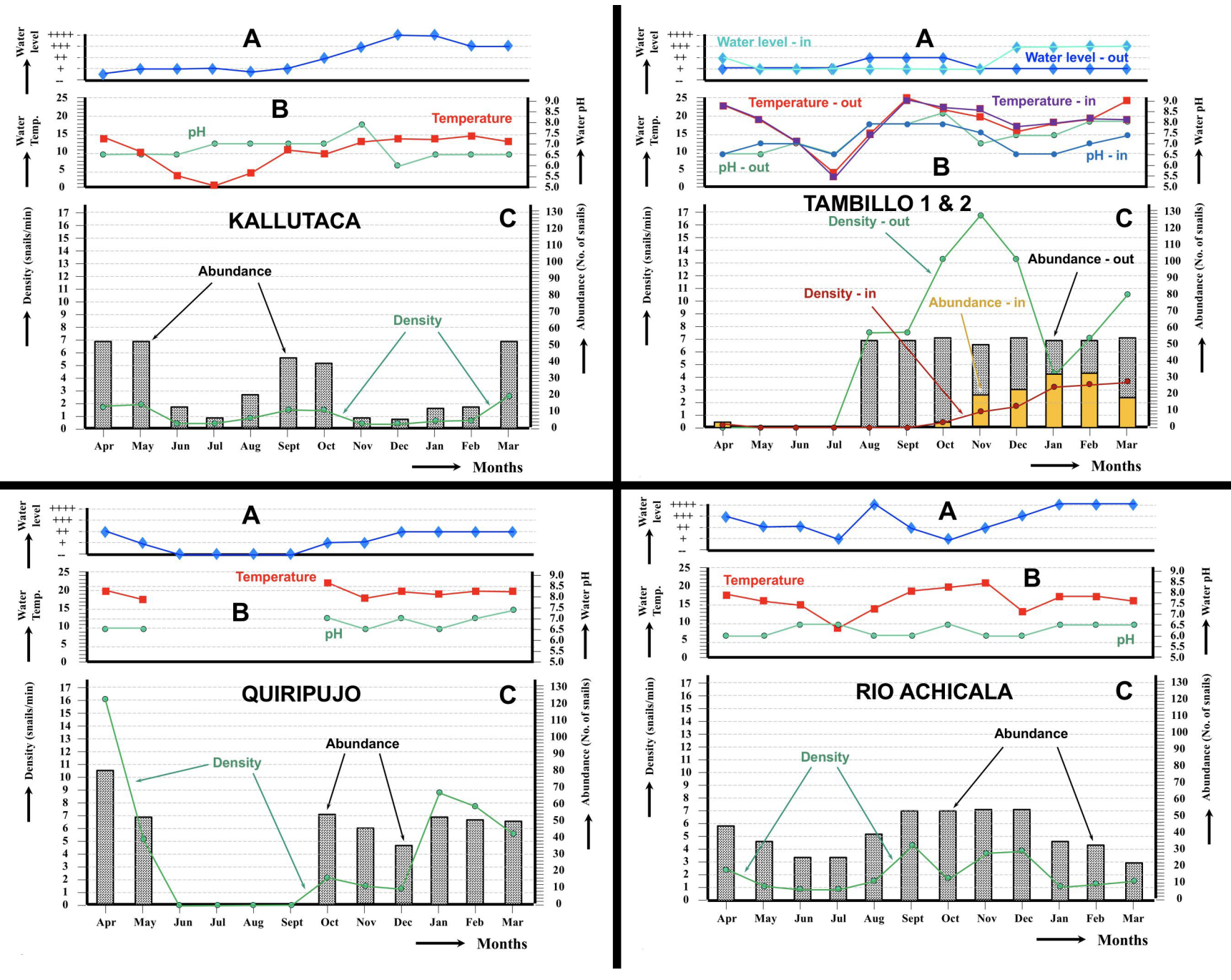

Figure 8. Monthly characteristics of the local freshwater habitats and dynamics of their respective inhabiting Galba truncatula populations in the transmission foci of Kallutaca, Tambillo 1 and 2 (in = inside village; out = outside village), Quiripujo and Rio Achicala: (A) water presence/absence and level; (B) water temperature and $\mathrm{pH}$; $(\mathrm{C})$ abundance and density of the lymnaeid populations.

as in Tambillo 1 and Tambillo 2, Quiripujo (Figure 7C), Chirapaca 1 and Chirapaca 2 (Figure 9C), where lymnaeid presence/absence significantly correlated with the presence/absence of available surface freshwater, except in Tambillo. In Tambillo, no snails were found during several months despite water presence, both inside and outside the village (Figure 8C). In Batallas, high numbers of lymnaeids were collected on mud in three discontinuous months in which no water was present (Figure 9C).

Abundance and density of the lymnaeid populations significantly correlated in transmission foci such as Kallutaca, Quiripujo, Rio Achicala (Figure 8C), Chirapaca 1, Batallas and Chijipata Alto (Figure 9C). However, in Tambillo 2 outside the village (Figure 8C) and in Chirapaca 2 (Figure 9C) the snails appeared more aggregated, i.e. with a higher density, in given months.

\section{Discussion}

\section{Molecular classification of lymnaeid populations}

The ITS-2 and ITS-1 markers proved that all snail populations studied belong to the species Galba truncatula. The two respective sequences were identical in all the transmission foci surveyed and correspond to those already reported from the same area before (Mas-Coma et al., 2001; Bargues et al., 2020). 


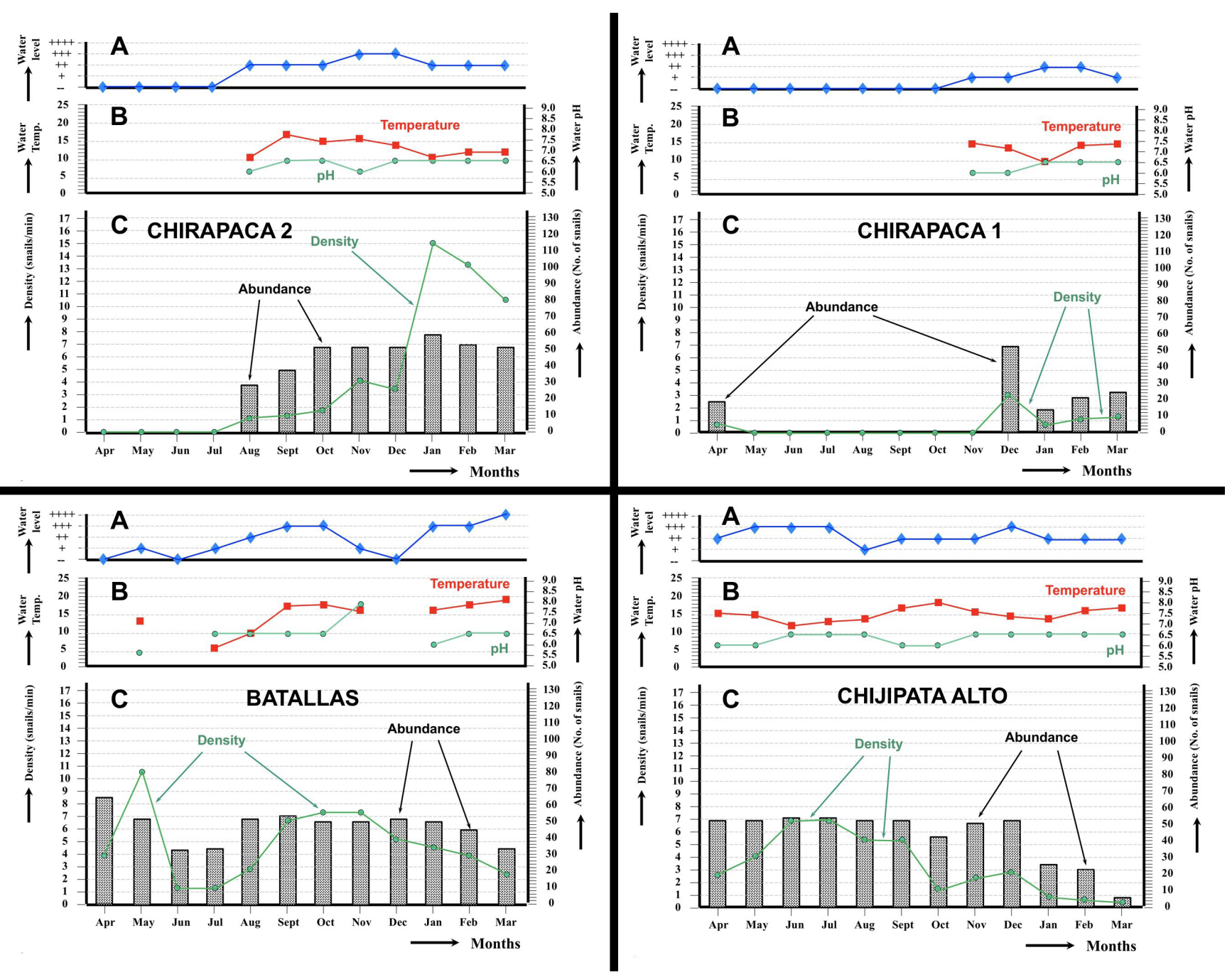

Figure 9. Monthly characteristics of the local freshwater habitats and dynamics of their respective inhabiting Galba truncatula populations in the transmission foci of Chirapaca 1, Chirapaca 2, Batallas and Chijipata Alto: (A) water presence/absence and its level (= depth); (B) water temperature and $\mathrm{pH}$; $(\mathrm{C})$ abundance and density of the lymnaeid populations.

In South America, F. hepatica is transmitted by different species of the co-called GalbalFossaria group (Bargues et al., 2007, 2011c). Interestingly, more than one Galba/Fossaria species co-exist in other human endemic areas: G. truncatula, L. schirazensis and L. neotropica in Cajamarca, Peru (Bargues et al., 2012); L. cousini, L. neotropica, L. schirazensis and L. cubensis in Ecuador (Bargues et al., 2011 b; Villavicencio et al., 2019); G. truncatula, L. cubensis and L. schirazensis in Venezuela (Bargues et al., 2011a); L. neotropica and L. viator in Argentina (Bargues et al., 2016); and G. truncatula and L. viator in Chile (Artigas et al., 2011). This high altitude scenario differs from fascioliasis in the lowlands, where fascioliasis is a veterinary problem in great part linked to the presence of a lymnaeid vector species not belonging to the Galba/Fossaria group as Pseudosuccinea columella, and human infection only appears in isolated cases, such as in Brazil (Maure et al., 1998; D'Almeida et al., 2016) and Uruguay (Bargues et al., 2017).

Given the well known different ecological requirements, ethological characteristics and liver fluke transmission capacities of the different Galba/Fossaria species (Bargues et al., 2017), dealing with only one snail species pronouncedly simplifies population comparisons, and the obtaining of significant results.

\section{Embryonation, growth, morphometry, fecundity and longevity}

The embryonic period of $11-14$ days at $20^{\circ} \mathrm{C}$ (Figure 5) fits well with what is known in G. truncatula. This period depends on the environmental temperature (Kendall, 1953): 32 days at $10-11^{\circ} \mathrm{C} ; 12-18$ days at $16-21^{\circ} \mathrm{C} ; 11-12$ days at $21-30^{\circ} \mathrm{C}$. According to the environmental (Figures 6 and 7) and water temperatures (Figures 8 and 9) of the foci, the embryonic period may vary between a longer period in the coldest winter to a shorter one in the other months. 
Shell growth in G. truncatula depends on the kind and quantity of nourishment (Kendall, 1953), although evident growth differences only appear in specimens from a size of $7 \mathrm{~mm}$ onwards (Rondelaud et al., 2009). In altiplanic G. truncatula maintained at $20^{\circ} \mathrm{C}$, the $6-\mathrm{mm}$ length is reached between 9 and 10 weeks of age, with a faster growth up to week 4 ( $0.971 \mathrm{~mm} /$ week) than between week 4 and week $10(0.280 \mathrm{~mm} /$ week), before entering in a very slowly increasing plateau from week 11 (Figure 5). The growing speed of altiplanic lymnaeids allowing them to reach a 4-mm length before week 4 is as fast as the experimental growth obtained when furnishing a supplementary diet (Rondelaud et al., 2009). This has epidemiological repercussions, given that the optimum period for infection by F. hepatica begins when lymnaeids reach the $4 \mathrm{~mm}$ size.

Measurements show that lymnaeids may reach a longer size in nature, although specimens longer than $10 \mathrm{~mm}$ are very rarely found in the Altiplano. This size may lead to confusion with the morphologically similar Succinea sp., a terrestrial species usually found in humid habitats and close to freshwater, which presents less dark-brownish shell, and eyes at the tip of tentacles (opposite to lymnaeids in which tentacles are triangular and the darkly pigmented eyes are located at the bases of tentacles). Succinea spp. have been sometimes confused with lymnaeids in fascioliasis areas (Lepe-López et al., 2020).

Egg laying begins in 4.0-4.5-mm-long G. truncatula (Walton \& Jones, 1926; Kendall, 1953; Smith, 1981). Thus, altiplanic $G$. truncatula are among the most precocious populations starting egg cluster laying, in several specimens even 1-2 days before week 4. Moreover, the egg laying capacity of 9-33 eggs/cluster (mean 17.5 eggs/cluster) of Bolivian G. truncatula is very high when compared to means of 12, 15 or 8.4 eggs/cluster reported by other authors (Kendall, 1953; Euzeby, 1971; Rondelaud et al., 2009). Similarly occurs with the mean of 87.1 eggs/snail/month of altiplanic lymnaeids. Quality and quantity of food have been argued to explain such differences in fecundity (Kendall, 1953). Owing to the fact that temperature also underlies fecundity differences (Kendall, 1953), such very high fecundity capacity of altiplanic G. truncatula in the laboratory should not be expected to occur in the Altiplano where air and water temperatures are lower than the standard permanent $20^{\circ} \mathrm{C}$ applied in our experimental procedures.

Longevity in G. truncatula usually varies between 6 and 12 months, although up to 17 months have been reported (Mehl, 1932). Altiplanic G. truncatula fit well within the aforementioned extremes. Experiments under temperatures differing during day and night hours (Table 3 ) indicate that the higher day temperatures compensate the a priori negatively influencing low night temperatures. Indeed, in the Altiplano mean temperatures do not fluctuate pronouncedly throughout a year, and the temperatures show marked differences between the maximum during sunshine hours and the minimum at night (Fuentes et al., 1999). This allows to understand that the longer life span of up to 12 months was observed in lymnaeids under temperatures of $22^{\circ} \mathrm{C} / 5^{\circ} \mathrm{C}$ day/night (Table 3 ).

In the Altiplano, G. truncatula may enter aestivation due to the lack of surface freshwater, and in hibernation due to cold temperature. Aestivation appears to be better supported by young than by adult specimens (Kendall, 1949; Roberts, 1950). Under natural conditions, G. truncatula can survive from 6 weeks up to 4.5 months in mud without water, and in the laboratory a whole year survival in a Petri dish without water has been reported (Kendall, 1949). Lymnaeids buried into the drying soil are more numerous in altitude habitats than in lowlands (Goumghar et al., 2001). Concerning hibernation, G. truncatula may be active up to a low temperature of $1.5^{\circ} \mathrm{C}$, although with reduced activity at low temperatures (Kendall, 1953). The appearance of ice reduces lymnaeid movements under the ice layer, as observed in Kallutaca. Aestivation and hybernation modify lymnaeid longevity and explain the longer longevities of up to 13-14 months observed in long-term laboratory adapted altiplanic G. truncatula kept in breeding boxes. Interestingly, altiplanic lymnaeids proved to survive longer to $F$. hepatica infection than lowland specimens (Bargues et al., 1995).

Unfortunately, the influence of the relative humidity cannot be assessed independently from temperature after the longevity experiments carried out (Table 3). However, the comparison of life spans at $16{ }^{\circ} \mathrm{C} / 9^{\circ} \mathrm{C}$ and $22^{\circ} \mathrm{C} / 5^{\circ} \mathrm{C}$ day/night and $65 \%$ relative humidity (assays $9-14$ in Table 3 ) with those under $25^{\circ} \mathrm{C} / 10^{\circ} \mathrm{C}$ day/night and $90 \%$ relative humidity (assay No. 8 in Table 3), suggests that a decreasing relative humidity accompanying the cold night temperatures may compose a better environment for altiplanic lymnaeids. Indeed, these are the climatic characteristics of the Bolivian Altiplano in winter (see Figures 6 and 7).

\section{Lymnaeid population dynamics, freshwater characteristics and climatic variables}

Differences of lymnaeid population dynamics were detected between the transmission foci (Figures 8C and 9C). Presence/absence and level (= depth) of freshwater on soil surface (Simon Vicente, 1968), differences between soil 
surface temperature and air temperature (Smith \& Wilson, 1980), soil humidity (Cruz-Mendoza et al., 2004), and to a lesser extent soil and water $\mathrm{pH}$ (Euzeby, 1971), are habitat microecology factors influencing lymnaeid population abundance, density and dynamics. In farms, different water bodies (e.g., pond, ditch, trench, furrow, moist area) show pronounced differences in G. truncatula population dynamics (Charlier et al., 2014).

The mean environmental temperature (MET) in the Northern Altiplano is lower than $10^{\circ} \mathrm{C}$ throughout a complete year (Fuentes et al., 1999). This was already highlighted because the intramolluscan larval stages of $F$. hepatica do not develop at temperatures lower than $9-10^{\circ} \mathrm{C}$ (Ollerenshaw, 1959; Fuentes et al., 1999). The present study shows that MET was lower than this minimum temperature threshold in all the months at the nine transmission foci (Figures 6B and 7B). However, local water temperature was always higher than that threshold in all these foci, excepting the winter months of June, July and August in a few of them. This explains why $F$. hepatica larval development goes on despite the low yearly MET. On the other side, neither MET nor local water temperature in the nine foci reached the maximum temperature threshold of $F$. hepatica, which is usually put at $26^{\circ} \mathrm{C}$ to allow for intramolluscan larval development and cercarial shedding (Afshan et al., 2014).

Optimum pH for lymnaeids ranges between 6.6 and 8.6 (Euzeby, 1971), although $G$. truncatula has also been found in acid soils with a pH of only 5.1 and in calcareous habitats with a pH of up to 9.0 (Euzeby, 1971). The abundance of $G$. truncatula is associated with soil and water pH (Charlier et al., 2014). Water pH measurements detected acid pHs in all monthly samples in Rio Achicala, Chirapaca 1, Chirapaca 2, Batallas and Chijipata Alto, whereas fluctuationes below and above the neutral pH in Kallutaca, Tambillo 1, Tambillo 2 and only sporadically above in Quiripujo (Figures 8B and 9B). This suggests the more successful G. truncatula populations to prefer altiplanic acid habitats.

The local availability of freshwater or sufficient soil surface humidity to maintain appropriate mud are main factors for Galba/Fossaria species. Rainfall and relative humidity are therefore key variables for fascioliasis transmission (Fuentes et al., 1999; Afshan et al., 2014; Fox et al., 2011). On the contrary, the very high evaporation and potential evapotranspiration at the very high altitude of the Altiplano eliminate temporary small water collections and surface humidity derived from rainfall quite rapidly. Such temporary habitats are therefore never inhabited by lymnaeids in the Bolivian Altiplano (Mas-Coma et al., 1999; Fuentes et al., 1999), i.e. in the Altiplano local rainfall has a negligible impact on fascioliasis transmission. In this area, the freshwater sources are either waters directly coming from the thaw and rain in the Eastern Andean Chain by means of rivers and streams, or on natural spring pools whose waters are provided from quite superficial phreatic layers leading the underground waters from the Eastern Andean Chain (Mas-Coma et al., 1999). Among the foci surveyed, neither the habitats presenting nonpermanent water, nor habitats presenting permanent water collections, depend on rainfall. Rainfall water appeared to be of some additional value only in the Quiripujo focus. Natural spring water pools from phreatic layers give rise to fascioliasis foci even far from the Eastern Andean Chain, as in the zone westward from Tiwanaku (Figure 1) (Mas-Coma et al., 1999).

\section{Transmission foci}

The intra- and interpopulation monthly variation comparisons of the 12-month curves of abundance and density of the altiplanic $G$. truncatula populations show differences between the transmission foci surveyed. Several aspects should be highlighted:

- There are habitats in which active lymnaeids are always present, e.g. those including permanent water collections (Kallutaca, Rio Achicala, Chijipata Alto) but also habitats in which water disappears for a short time during which lymnaeids keep activity on mud (Batallas);

- There are other habitats in which lymnaeids could not be found in several monthly surveys, e.g. in water absence (Quiripujo, Chirapaca 1, Chirapaca 2), but also others where water was always available (Tambillo 1, Tambillo 2). In the former, the abundant lymnaeids in the first month with water after the dry months suggests that lymnaeids were hibernating buried in soil;

- The concentrated presence of human activity waste chronologically correlates with the absence of lymnaeids despite the permanent availability of water, in the focus inside Tambillo village during a five month period (May to September). A slow population recovery occurs afterwards (October-November) and a progressive decline later (March-April) with increasing waste concentration after the higher water level period. This differs from the only 30 m distant focus outside Tambillo;

- Marked differences in abundance and density were found in neighboring foci (Chirapaca 1, Chirapaca 2) depending on habitat type and the period without water. In these close foci, the different snail size indicates 
different generation moments (e.g. many adults in one site whereas only scarce small specimens in the other site);

- Nothing suggests the distance between the transmission foci and the Lake Titicaca to have an influence on the population dynamics.

One, two or three generation patterns have been reported to occur in G. truncatula populations throughout a whole year, depending on the characteristics of the transmission focus (Rondelaud et al., 2009). Moreover, egglaying dates vary according to local climatic conditions independently of the generation pattern (Smith \& Wilson, 1980). In the Altiplano, the coexistence of small juveniles and large adult specimens in the same habitat are mainly detected in November-December (Tambillo 1, Rio Achicala, Chirapaca 2, Batallas, Chijipata Alto) and February-March (Kallutaca, Tambillo 2, Quiripujo, Chirapaca 1), that is, beginning and end of the rainy season which also correspond to the year period in which the mean minimum air temperatures $(\mathrm{MmT})$ are less low and water temperatures are higher. Results suggest that, in the Altiplano, two patterns may occur: (i) a two generations/year pattern in habitats with permanent water and sufficiently humid short period assuring mud availability, and (ii) a one generation/year pattern in habitats with lack of water availability during several months. Abundance and density curves in habitats with permanent populations (Kallutaca, Rio Achicala, Batallas, Chijipata Alto) illustrate the aforementioned two generations/year pattern (Figures 8C and 9C).

These results fit well with epidemiological data indicating that the infection risk for humans and livestock covers the whole year. This is due to the infectivity of metacercariae, which lasts up to 31 weeks, i.e. almost 8 months (Valero \& Mas-Coma, 2000; Valero et al., 2002) and defines the so-called "altiplanic transmission pattern" of fascioliasis (Mas-Coma et al., 2009a, 2014a).

\section{Concluding Remarks}

From the point of view of the One Health initiative in the Northern Bolivian Altiplano hyperendemic area, experimental and field results allow to conclude that the multidisciplinary control measures can be extended from one part of the endemic area to another. It should be remembered that, in this endemic area, all lymnaeid populations are molecularly clonic, i.e. genetically identical due to the fecundation of Galba truncatula by selfing, an evolutionary strategy enhanced under the extreme conditions of the very high altitude conditions (Bargues et al., 2020). It is evident that local microecological conditions differing from one transmission focus to another may give rise to some field variability in the characteristics analyzed in the experimental growth and the field followup studies, but the physiographic and climatic uniformity of the endemic corridors at the Altiplano endemic area, together with the genetic monomorphism of the snails, suggest the extrapolation potential of the data obtained.

The diversity of habitat types and differing respective population dynamics of the only one lymnaeid species found, G. truncatula, agree with present knowledge on these aspects in situations where this lymnaeid species is the only transmitting snail present, as in Europe. Indeed, the singularity detected in given characteristics are linked to the extreme conditions of the very high altitude, which are similar throughout the endemic area.

The experimental and field studies here reported concern a very high altitude endemic area of human and animal fascioliasis for the first time. They offer the necessary methodological baseline and an overview example of the lymnaeid vector scenario in a human hyperendemic area for such kind of needed studies still to be implemented in high altitude fascioliasis endemic areas in other tropical and subtropical countries of Latin America.

\section{Acknowledgements}

Studies of this article have been performed within the framework of the Worldwide Initiative of WHO against Human Fascioliasis (WHO Headquarters, Geneva, Switzerland). Studies funded by Project No. 2017/ACDE/001583 de Innovación para el Desarrollo of the Agencia Española de Cooperación Internacional para el Desarrollo (AECID), Ministry of Foreign Affairs and Cooperation, Madrid, Spain; by Health Research Project No. PI16/00520, Subprograma Estatal de Generación de Conocimiento de la Acción Estratégica en Salud (AES) y Fondos FEDER, Plan Estatal de Investigación Científica y Técnica y de Innovación, ISCIII-MINECO, Madrid, Spain; by the Red de Investigación de Centros de Enfermedades Tropicales - RICET (Project No. RD16/0027/0023 of the PN de I+D+I, ISCIII-Subdirección General de Redes y Centros de Investigación Cooperativa RETICS), Ministry of Health and Consumption, Madrid; by Project No. 2016/099 of the PROMETEO Program, Programa of Ayudas para Grupos de Investigación de Excelencia, Generalitat Valenciana, Valencia, Spain; and by Project No. 2017/01 of the V Convocatoria de Proyectos de Cooperación al Desarrollo de la Universidad de Valencia de 2016, Valencia, Spain. The funders had no role in 
study design, data collection and analysis, decision to publish, or preparation of the manuscript. Dr. Pablo Cuervo benefited from a scholarship funded by the Programa BEC.AR 2017 of the Ministry of Education, Culture, Science and Technology, Buenos Aires, Argentina, for a three month research stay in the Parasitology Centre of Valencia. The following collaborations are greatly acknowledged: Dr. M. Franken (La Paz, Bolivia) in the physico-chemical characterization of the freshwater collections; Dr. A. Rodriguez (Valencia, Spain) and Biology Graduate H.C.T. Vargas (Liège, Belgium) in the experimental assays with laboratory-reared snails. Technical support provided by the Servicio Central de Secuenciación para la Investigación Experimental (SCSIE) of the Universidad de Valencia (Dr. A. Martínez).

\section{References}

Afshan K, Fortes-Lima CA, Artigas P, Valero MA, Qayyum M, Mas-Coma S. Impact of climate change and man-made irrigation systems on the transmission risk, long-term trend and seasonality of human and animal fascioliasis in Pakistan. Geospat Health 2014; 8(2): 317-334. http://dx.doi.org/10.4081/gh.2014.22. PMid:24893010.

Apt W, Aguilera X, Vega F, Alcaíno H, Zulantay I, Apt P, et al. Prevalencia de fascioliasis en humanos, caballos, cerdos y conejos silvestres, en tres provincias de Chile. Bol Of Sanit Panam (Engl) 1993; 115(5): 405-414.

Artigas P, Bargues MD, Mera y Sierra R, Agramunt VH, Mas-Coma S. Characterisation of fascioliasis lymnaeid intermediate hosts from Chile by DNA sequencing, with emphasis on Lymnaea viator and Galba truncatula. Acta Trop 2011; 120(3): 245-257. http:// dx.doi.org/10.1016/j.actatropica.2011.09.002. PMid:21933653.

Baird RB, Eaton AD, Rice EW. Standard methods for the examination of water and wastewater. 23rd ed. Washington, DC: American Public Health Association, American Water Works Association and Water Environment Federation; 2017.

Bargues MD, Oviedo JA, Funatsu IR, Rodriguez A, Mas-Coma S. Survival of lymnaeid snails from the Bolivian Northern Altiplano after the parasitation by different Bolivian isolates of Fasciola hepatica (Linnaeus, 1758) (Trematoda: Fasciolidae). In: Guerra A, Rolán E, Rocha F. Unitas Malacologica. Vigo: Instituto de Investigaciones Marinas, CSIC; 1995. p. 443-445.

Bargues MD, Mangold AJ, Muñoz-Antoli C, Pointier JP, Mas-Coma S. SSU rDNA characterization of lymnaeid snails transmitting human fascioliasis in South and Central America. J Parasitol 1997; 83(6): 1086-1092. http://dx.doi.org/10.2307/3284367. PMid:9406784.

Bargues MD, Horák P, Patzner RA, Pointier JP, Jackiewicz M, Meier-Brook C, et al. Insights into the relationships of Palaearctic and Nearctic lymnaeids (Mollusca: Gastropoda) by rDNA ITS-2 sequencing and phylogeny of stagnicoline intermediate host species of Fasciola hepatica. Parasite 2003; 10(3): 243-255. http://dx.doi.org/10.1051/parasite/2003103243. PMid:14535164.

Bargues MD, Artigas P, Mera y Sierra R, Pointier JP, Mas-Coma S. Characterisation of Lymnaea cubensis, L. viatrix and L. neotropica n. sp., the main vectors of Fasciola hepatica in Latin America, by analysis of their ribosomal and mitochondrial DNA. Ann Trop Med Parasitol 2007; 101(7): 621-641. http://dx.doi.org/10.1179/136485907X229077. PMid:17877881.

Bargues MD, González C, Artigas P, Mas-Coma S. A new baseline for fascioliasis in Venezuela: lymnaeid vectors ascertained by DNA sequencing and analysis of their relationships with human and animal infection. Parasit Vectors 2011a; 4(1): 200. http:// dx.doi.org/10.1186/1756-3305-4-200. PMid:21999170.

Bargues MD, Artigas P, Khoubbane M, Mas-Coma S. DNA sequence characterisation and phylogeography of Lymnaea cousini and related species, vectors of fascioliasis in northern Andean countries, with description of L. meridensis n. sp. (Gastropoda: lymnaeidae). Parasit Vectors 2011b; 4(1): 132. http://dx.doi.org/10.1186/1756-3305-4-132. PMid:21749718.

Bargues MD, Artigas P, Khoubbane M, Flores R, Glöer P, Rojas-Garcia R, et al. Lymnaea schirazensis, an overlooked snail distorting fascioliasis data: genotype, phenotype, ecology, worldwide spread, susceptibility, applicability. PLoS One 2011c; 6(9): e24567. http://dx.doi.org/10.1371/journal.pone.0024567. PMid:21980347.

Bargues MD, Artigas P, Khoubbane M, Ortiz P, Naquira C, Mas-Coma S. Molecular characterisation of Galba truncatula, Lymnaea neotropica and L. schirazensis from Cajamarca, Peru and their potential role in transmission of human and animal fascioliasis. Parasit Vectors 2012; 5(1): 174. http://dx.doi.org/10.1186/1756-3305-5-174. PMid:22894178.

Bargues MD, Malandrini JB, Artigas P, Soria CC, Velásquez JN, Carnevale S, et al. Human fascioliasis endemic areas in Argentina: multigene characterisation of the lymnaeid vectors and climatic-environmental assessment of the transmission pattern. Parasit Vectors 2016; 9(1): 306. http://dx.doi.org/10.1186/s13071-016-1589-z. PMid:27229862.

Bargues MD, Gayo V, Sanchis J, Artigas P, Khoubbane M, Birriel S, et al. DNA multigene characterization of Fasciola hepatica and Lymnaea neotropica and its fascioliasis transmission capacity in Uruguay, with historical correlation, human report review and infection risk analysis. PLoS Neg/ Trop Dis 2017; 11(2): e0005352. http://dx.doi.org/10.1371/journal.pntd.0005352. PMid:28158188.

Bargues MD, Artigas P, Angles R, Osca D, Duran P, Buchon P, et al. Genetic uniformity, geographical spread and anthropogenic habitat modifications of lymnaeid vectors found in a One Health initiative in the highest human fascioliasis hyperendemic of the Bolivian Altiplano. Parasit Vectors 2020; 13(1): 171. http://dx.doi.org/10.1186/s13071-020-04045-x. PMid:32252808. 
Bjorland J, Bryan RT, Strauss W, Hillyer GV, McAuley JB. An outbreak of acute fascioliasis among Aymara Indians in the Bolivian Altiplano. Clin Infect Dis 1995; 21(5): 1228-1234. http://dx.doi.org/10.1093/clinids/21.5.1228. PMid:8589147.

Boulangé B, Aquize Jaen E. Morphologie, hydrographie et climatologie du Lac Titicaca et de son bassin versant. Rev Hydrobiol Trop Paris 1981; 14(4): 269-287.

Charlier J, Soenen K, De Roeck E, Hantson W, Ducheyne E, Van Coillie F, et al. Longitudinal study on the temporal and microspatial distribution of Galba truncatula in four farms in Belgium as a base for small-scale risk mapping of Fasciola hepatica. Parasit Vectors 2014; 7(1): 528. http://dx.doi.org/10.1186/s13071-014-0528-0. PMid:25425397.

Chen MG, Mott KE. Progress in assessment of morbidity due to Fasciola hepatica infection: a review of recent literature. Trop Dis Bull 1990; 87(4): R1-R38.

Cruz-Mendoza I, Figueroa JA, Correa D, Ramos-Martinez E, Lecumberri-López J, Quiroz-Romero H. Dynamics of Fasciola hepatica infection in two species of snails in a rural locality of Mexico. Vet Parasitol 2004; 121(1-2): 87-93. http://dx.doi.org/10.1016/j. vetpar.2004.02.006. PMid:15110406.

D'Almeida SCG, Freitas DF, Carneiro MB, Camargo PF, Azevedo JC, Martins IVF. The population density of Lymnaea columella (Say, 1817) (Mollusca, Lymnaeidae) an intermediate host of Fasciola hepatica (Linnaeus, 1758), in the Caparaó Microregion, ES, Brazil. Braz J Biol 2016; 76(2): 334-340. http://dx.doi.org/10.1590/1519-6984.14314. PMid:26934156.

Dejoux C, Iltis A. Lake Titicaca. A synthesis of limnological knowledge. Dordrecht: Kluwer Academic Publishers; 1992. http://dx.doi. org/10.1007/978-94-011-2406-5.

Esteban JG, Flores A, Angles R, Strauss W, Aguirre C, Mas-Coma S. A population-based coprological study of human fascioliasis in a hyperendemic area of the Bolivian Altiplano. Trop Med Int Health 1997; 2(7): 695-699. http://dx.doi.org/10.1046/j.1365-3156.1997. d01-356.x. PMid:9270738.

Euzeby J. Les maladies vermineuses des animaux domestiques et leurs incidences sur la pathologie humaine. In: Euzeby J. Maladies dues aux Plathelminthes. Part 2. Trématodes. Book 1. Généralités. Distomatoses hépato-biliaires. Tome II. Paris: Editions Vigot; 1971.

Fox NJ, White PCL, McClean CJ, Marion G, Evans A, Hutchings MR. Predicting impacts of climate change on Fasciola hepatica risk. PLoS One 2011; 6(1): e16126. http://dx.doi.org/10.1371/journal.pone.0016126. PMid:21249228.

Fuentes MV, Valero MA, Bargues MD, Esteban JG, Angles R, Mas-Coma S. Analysis of climatic data and forecast indices for human fascioliasis at very high altitude. Ann Trop Med Parasitol 1999; 93(8): 835-850. http://dx.doi.org/10.1080/00034983.1999.11813 491. PMid:10715678.

Fuentes MV, Malone JB, Mas-Coma S. Validation of a mapping and predicting model for human fasciolosis transmission in Andean very high altitude endemic areas using remote sensing data. Acta Trop 2001; 79(1): 87-95. http://dx.doi.org/10.1016/ S0001-706X(01)00106-1. PMid:11378145.

Gironés N, Valero MA, Garcia-Bodelon MA, Chico-Calero MI, Punzon C, Fresno M, et al. Immune supression in advanced chronic fascioliasis: an experimental study in a rat model. J Infect Dis 2007; 195(10): 1504-1512. http://dx.doi.org/10.1086/514822. PMid:17436231.

González LC, Esteban JG, Bargues MD, Valero MA, Ortiz P, Náquira C, et al. Hyperendemic human fascioliasis in Andean valleys: an altitudinal transect analysis in children of Cajamarca province, Peru. Acta Trop 2011; 120(1-2): 119-129. http://dx.doi.org/10.1016/j. actatropica.2011.07.002. PMid:21767521.

González-Miguel J, Valero MA, Reguera-Gomez M, Mas-Bargues C, Bargues MD, Simón F, et al. Numerous Fasciola plasminogenbinding proteins may underlie blood-brain barrier leakage and explain neurological disorder complexity and heterogeneity in the acute and chronic phases of human fascioliasis. Parasitology 2019; 146(3): 284-298. http://dx.doi.org/10.1017/S0031182018001464. PMid:30246668.

Goumghar MD, Rondelaud D, Dreyfuss G, Benlemlih M. Influence of aestivation on the survival of Galba truncatula (Mollusca: Gastropoda) populations according to altitude. Ann Limnol - Int J Lim 2001; 37(3): 211-217. https://doi.org/10.1051/limn/2001018.

Hach Company. Hach Water Analysis Handbook. 7th ed. Loveland, Colorado: Hach Company; 2012.

Hillyer GV, de Lagrava MS, Bryan RT, Bjorland J, Rodriguez-Perez J, Guzman SR, et al. Use of the Falcon ${ }^{\text {TM }}$ Assay Screening Test - Enzyme-Linked Immunosorbent Assay (FAST-ELISA) and the Enzyme-Linked Immunoelectrotransfer Blot (EITB) to determine the prevalence of human fascioliasis in the Bolivian Altiplano. Am J Trop Med Hyg 1992; 46(5): 603-609. http://dx.doi.org/10.4269/ ajtmh.1992.46.603. PMid:1599055.

Hubendick B. Recent Lymnaeidae. Their variation, morphology, taxonomy, nomenclature, and distribution. Fjärde: Almqvist \& Wiksell; 1951. Serien 3. Kongliga Svenska Vetenskaps-akademiens handlingar.

Kendall SB. Bionomics of Limnaea truncatula and the parthenitae of Fasciola hepatica under drought conditions. J Helminthol 1949; 23(1-2): 57-68. http://dx.doi.org/10.1017/S0022149X00032375. 
Kendall SB. The life-history of Limnaea truncatula under laboratory conditions. J Helminthol 1953; 27(1-2): 17-28. http://dx.doi. org/10.1017/S0022149X00023476.

Larkin M, Blackshields G, Brown N, Chenna R, McGettigan P, McWilliam H, et al. Clustal W and Clustal X version 2.0. Bioinformatics 2007; 23(21): 2947-2948. http://dx.doi.org/10.1093/bioinformatics/btm404. PMid:17846036.

Lepe López MA, Villatoro-Paz E, Valdez Sandoval JC, Rios LV, Diaz Rodríguez M, Guerra Centeno DS. Reporte de Pseudosuccinea columella infectados con Fasciola hepatica en Sierra de los Cuchumatanes, Guatemala. Mvz Córdoba 2020; 25(1): 1616. http:// dx.doi.org/10.21897/rmvz.1616.

Malandrini JB, Carnevale S, Velazquez J, Soria CC. Diagnóstico de Fasciola hepatica con la técnica de ELISA en el Departamento de Tinogasta. Ciencia 2009; 4(10): 143-151.

Mas-Coma S, Anglés R, Esteban JG, Bargues MD, Buchon P, Franken M, et al. The Northern Bolivian Altiplano: a region highly endemic for human fascioliasis. Trop Med Int Health 1999; 4(6): 454-467. http://dx.doi.org/10.1046/j.1365-3156.1999.00418.x. PMid:10444322.

Mas-Coma S, Funatsu IR, Bargues MD. Fasciola hepatica and lymnaeid snails occurring at very high altitude in South America. Parasitology 2001;123(7 Suppl): S115-127. http://dx.doi.org/10.1017/S0031182001008034. PMid:11769277.

Mas-Coma S, Valero MA, Bargues MD. Chapter 2. Fasciola, lymnaeids and human fascioliasis, with a global overview on disease transmission, epidemiology, evolutionary genetics, molecular epidemiology and control. Adv Parasito/ 2009a; 69: 41-146. http:// dx.doi.org/10.1016/S0065-308X(09)69002-3. PMid:19622408.

Mas-Coma S, Valero MA, Bargues MD. Climate change effects on trematodiases, with emphasis on zoonotic fascioliasis and schistosomiasis. Vet Parasito/ 2009b; 163(4): 264-280. http://dx.doi.org/10.1016/j.vetpar.2009.03.024. PMid:19375233.

Mas-Coma S, Bargues MD, Valero MA. Diagnosis of human fascioliasis by stool and blood techniques: update for the present global scenario. Parasitology 2014a; 141(14): 1918-1946. http://dx.doi.org/10.1017/S0031182014000869. PMid:25077569.

Mas-Coma S, Agramunt VH, Valero MA. Neurological and ocular fascioliasis in humans. Adv Parasitol 2014b; 84: 27-149. http:// dx.doi.org/10.1016/B978-0-12-800099-1.00002-8. PMid:24480313.

Mas-Coma S, Bargues MD, Valero MA. Human fascioliasis infection sources, their diversity, incidence factors, analytical methods and prevention measures. Parasitology 2018; 145(13): 1665-1699. http://dx.doi.org/10.1017/S0031182018000914. PMid:29991363.

Mas-Coma S, Buchon P, Funatsu IR, Angles R, Artigas P, Valero MA, et al. Sheep and cattle reservoirs in the highest human fascioliasis hyperendemic area: experimental transmission capacity, field epidemiology, and control within a One Health initiative in Bolivia. Front Vet Sci 2020; 7: 583204. http://dx.doi.org/10.3389/fvets.2020.583204. PMid:33195605.

Maure EAP, Bustamante M, Serra-Freire NM, Gomes DC. Dinâmica de Lymnaea columella (Say, 1817), hospedeiro intermediário de Fasciola hepatica (Linnaeus, 1758) em municípios do Estado de São Paulo, Brasil. Braz J Vet Res Anim Sci 1998; 35(4): 151-155.

Mehl, S. Die Lebensbedingungen der Leberegelschnecke (Galba truncatula Müller). Untersuchungen über Schale, Verbreitung, Lebensgeschichte, natürliche Feinde und Bekämpfungsmöglichkeiten. Arbeiten aus der Bayerischen Landesanstalt für Pflanzenbau und Pflanzenschutz. Verlag: Freising-München Verlag Dr F P Datterer \& Cie; 1932.

Mehmood K, Zhang H, Sabir AJ, Abbas RZ, Ijaz M, Durrani AZ, et al. A review on epidemiology, global prevalence and economical losses of fasciolosis in ruminants. Microb Pathog 2017; 109: 253-262. http://dx.doi.org/10.1016/j.micpath.2017.06.006. PMid:28602837.

Mera y Sierra R, Agramunt VH, Cuervo P, Mas-Coma S. Human fascioliasis in Argentina: retrospective overview, critical analysis and baseline for future research. Parasit Vectors 2011; 4(1): 104. http://dx.doi.org/10.1186/1756-3305-4-104. PMid:21663691.

National Center for Biotechnology Information - NBCI. Basic local alignment search tool [online]. 2020 [cited 2016 July 3]. Available from: http://www.ncbi.nlm.nih.gov/BLAST

Ollerenshaw CB. The ecology of the liver fluke (Fasciola hepatica). Vet Rec 1959; 71(45): 957-965.

Relf V, Good B, Hanrahan JP, McCarthy E, Forbes AB, de Waal T. Temporal studies on Fasciola hepatica in Galba truncatula in the west of Ireland. Vet Parasitol 2011; 175(3-4): 287-292. http://dx.doi.org/10.1016/j.vetpar.2010.10.010. PMid:21111536.

Rinaldi L, Gonzalez S, Guerrero J, Aguilera LC, Musella V, Genchi C, et al. A One-Health integrated approach to control fascioliasis in the Cajamarca valley of Peru. Geospat Health 2012; 6(3): S67-S73. http://dx.doi.org/10.4081/gh.2012.124. PMid:23032285.

Roberts EW. Studies on the life-cycle of Fasciola hepatica (Linnaeus) and of its snail host, Limnaea (Galba) truncatula (Müller) in the field and under controlled conditions in the laboratory. Ann Trop Med Parasitol 1950; 44(2): 187-206. http://dx.doi.org/10.1 080/00034983.1950.11685441. PMid:24538002.

Rondelaud D, Vignoles P, Dreyfuss G. La Limnée tronquée. Un mollusque d'intérêt médical et vétérinaire. Limoges: Presses Universitaires de Limoges; 2009. 
Samadi S, Roumegoux A, Bargues MD, Mas-Coma S, Yong M, Pointier JP. Morphological studies of lymnaeid snails from the human fascioliasis endemic zone of Bolivia.J Moll Stud 2000; 66(1): 31-44. http://dx.doi.org/10.1093/mollus/66.1.31.

Simon Vicente F. Datos sobre la ecología de L. truncatula y la evolución larvaria de F. hepatica en una zona de regadío. Rev lber Parasitol 1968; 28: 333-348.

Smith G, Wilson RA. Seasonal variations in the microclimate of Lymnaea truncatula habitats. J Appl Ecol 1980; $17(2)$ : $329-342$. http://dx.doi.org/10.2307/2402329.

Smith G. Copulation and oviposition of Lymnaea truncatula (Müller). J Mol/ Stud 1981; 47(1): 108-111. http://dx.doi.org/10.1093/ oxfordjournals.mollus.a065549.

Tamura K, Stecher G, Peterson D, Filipski A, Kumar S. MEGA6: Molecular Evolutionary Genetics Analysis version 6.0. Mol Biol Evol 2013; 30(12): 2725-2729. http://dx.doi.org/10.1093/molbev/mst197. PMid:24132122.

Valero MA, Mas-Coma S. Comparative infectivity of Fasciola hepatica metacercariae from isolates of the main and secondary reservoir animal host species in the Bolivian Altiplano high human endemic region. Folia Parasitol (Praha) 2000; 47(1): 17-22. http://dx.doi.org/10.14411/fp.2000.004. PMid:10833011.

Valero MA, Panova M, Comes AM, Fons R, Mas-Coma S. Patterns in size and shedding of Fasciola hepatica eggs by naturally and experimentally infected murid rodents. J Parasito/ 2002; 88(2): 308-313. http://dx.doi.org/10.1645/0022-3395(2002)088[0308:PI SASO]2.0.CO;2. PMid:12054003.

Valero MA, Panova M, Mas-Coma S. Phenotypic analysis of adults and eggs of Fasciola hepatica by computer image analysis system. J Helminthol 2005; 79(3): 217-225. http://dx.doi.org/10.1079/JOH2005301. PMid:16153315.

Valero MA, Navarro M, Garcia-Bodelon MA, Marcilla A, Morales M, Hernandez JL, et al. High risk of bacterobilia in advanced experimental chronic fasciolosis. Acta Trop 2006; 100(1-2): 17-23. http://dx.doi.org/10.1016/j.actatropica.2006.09.002. PMid:17064656.

Valero MA, Gironès N, Garcia-Bodelon MA, Periago MV, Chico-Calero I, Khoubbane M, et al. Anaemia in advanced chronic fasciolosis. Acta Trop 2008; 108(1): 35-43. http://dx.doi.org/10.1016/j.actatropica.2008.08.007. PMid:18805388.

Valero MA, Perez-Crespo I, Khoubbane M, Artigas P, Panova M, Ortiz P, et al. Fasciola hepatica phenotypic characterisation in Andean human endemic areas: valley versus altiplanic patterns analysed in liver flukes from sheep from Cajamarca and Mantaro, Peru. Infect Genet Evol 2012a; 12(2): 403-410. http://dx.doi.org/10.1016/j.meegid.2012.01.009. PMid:22285769.

Valero MA, Periago MV, Perez-Crespo I, Anglés R, Villegas F, Aguirre C, et al. Field evaluation of a coproantigen detection test for fascioliasis diagnosis and surveillance in human hyperendemic areas of Andean countries. PLoS Neg/ Trop Dis 2012b; 6(9): e1812. http://dx.doi.org/10.1371/journal.pntd.0001812. PMid:23029575.

Valero MA, Bargues MD, Khoubbane M, Artigas P, Quesada C, Berinde L, et al. Higher physiopathogenicity by Fasciola gigantica than by the genetically close $F$. hepatica: experimental long-term follow-up of biochemical markers. Trans $R$ Soc Trop Med Hyg 2016; 110(1): 55-66. http://dx.doi.org/10.1093/trstmh/trv110. PMid:26740363.

Valero MA, Perez-Crespo I, Chillón-Marinas C, Khoubbane M, Quesada C, Reguera-Gómez M, et al. Fasciola hepatica reinfection potentiates a mixed Th1/Th2/Th17/Treg response and correlates with the clinical phenotypes of anemia. PLoS One 2017; 12(3): e0173456. http://dx.doi.org/10.1371/journal.pone.0173456. PMid:28362822.

Villavicencio AF, Bargues MD, Artigas A, Guamán R, Ulloa SM, Romero J, et al. Lymnaeid snail vectors of fascioliasis, including the first finding of Lymnaea neotropica in Ecuador, assessed by ribosomal DNA sequencing in the southern zone close to the Peru border. Acta Parasitol 2019; 64(4): 839-849. http://dx.doi.org/10.2478/s11686-019-00104-1. PMid:31420774.

Villegas F, Angles R, Barrientos R, Barrios G, Valero MA, Hamed K, et al. Administration of triclabendazole is safe and effective in controlling fascioliasis in an endemic community of the Bolivian Altiplano. PLoS Neg/ Trop Dis 2012; 6(8): e1720. http://dx.doi. org/10.1371/journal.pntd.0001720. PMid:22880138.

Walton CL, Jones WN. Further observations on the life-history of Limnaea truncatula. Parasitology 1926; 18(2): 144-147. http:// dx.doi.org/10.1017/S0031182000005084.

Webster JP, Gower CM, Knowles SCL, Molyneux DH, Fenton A. One health - an ecological and evolutionary framework for tackling Neglected Zoonotic Diseases. Evol App/ 2016; 9(2): 313-333. http://dx.doi.org/10.1111/eva.12341. PMid:26834828.

World Health Organization - WHO. Sustaining the drive to overcome the global impact of neglected tropical diseases. Geneva: Department of Control of Neglected Tropical Diseases, World Health Organization, WHO Headquarters; 2013.

Zumaquero-Ríos JL, Sarracent-Pérez J, Rojas-García R, Rojas-Rivero L, Martinez-Tovilla Y, Valero MA, et al. Fascioliasis and intestinal parasitoses affecting schoolchildren in Atlixco, Puebla State, Mexico: epidemiology and treatment with nitazoxanide. PLoS Neg/ Trop Dis 2013; 7(11): e2553. http://dx.doi.org/10.1371/journal.pntd.0002553. PMid:24278492. 